\title{
16.2 TEMPLATE DEPOSITION OF METALS
}

\author{
Paolo Ugo and Ligia Maria Moretto \\ Department of Physical Chemistry, University of Venice, \\ Santa Marta 2137, 30123 Venice, Italy
}

\subsubsection{Introduction}

Template synthesis is a relatively simple and easy procedure which has made the fabrication of rather sophisticated nanomaterials accessible to almost any laboratory. Template synthesis requires access to instrumentation capable of metal sputtering and electrochemical deposition. The characterization of the fabricated nanostructures can be done using instrumental techniques including spectrophotometry, voltammetry, optical microscopy, atomic force microscopy, and electronic microscopies (scanning electron microscopy (SEM) and transmission electron microscopy (TEM)).

The method is based on the simple but effective idea that the pores of a host material can be used as a template to direct the growth of new materials. Historically, template synthesis was introduced by Possin (1) and refined by Williams and Giordano (2) who prepared different metallic nanowires with widths as small as $10 \mathrm{~nm}$ within the pores of etched nuclear damaged tracks in mica. It was further developed by Martin's group (3-5) and followed by others (6) with the number of examples and applications (7) continually increasing. The nanoporous membranes usually employed as templates are alumina or track-etched polymeric membranes which are widely used as ultrafiltration membranes. Recently, metal nanostructures have also been obtained using the pores created by self-assembly in block copolymer structures under the influence of electric fields and high temperatures $(8,9)$.

The first part of this section focuses on the main characteristics and fabrication techniques used for obtaining templating membranes and depositing metal nanostructures by suitable electroless and electrochemical procedures. Methods such as sol-gel (10-12) or chemical vapor deposition $(10,13)$, which have been used primarily for the template deposition of carbon, oxides, or semiconducting-based materials, will not be considered here in detail. The second part of the section focuses on the electrochemical properties of the fabricated nanomaterials with emphasis on the characteristics and applications of nanoelectrode ensembles (NEEs).

\subsubsection{Templating membranes}

\subsubsection{Alumina membranes}

Aluminum oxide films with regular pore distribution can be formed by electrooxidation of high-purity aluminum substrates in acidic electrolytes $(14,15)$. The structure of the oxide film consists of a uniform array of parallel alumina cells packed hexagonally, each containing a nearly cylindrical pore. The uniform diameter of the pores is a consequence of the 
equilibrium between the growth rate of the alumina and its dissolution in the acidic electrolyte. The hexagonal self-order of the pores can be explained by the repulsive forces due to the volume expansion associated with the anodization process (14). By appropriate selection of the process conditions, films with pore diameters between $<10 \mathrm{~nm}$ up to $2 \mu \mathrm{m}$, pore density between $10^{8}$ and $10^{11}$ pores $\mathrm{cm}^{-2}$, and film thickness up to $200 \mu \mathrm{m}$ can be prepared (16).

The electrolysis of aluminum is carried out in a two-electrode cell. The anode is usually a high-purity (99.9\% or even $99.99 \%$ ) aluminum sheet. The metal surface must be carefully cleaned via chemical or electrochemical polishing (17). After degreasing in 1:2:1 ethanol-dichloromethane-acetone solution (17), the aluminum surface is cleaned by immersion in $\mathrm{NaOH}$ ( $1 \mathrm{M}(18)$ or $0.05 \mathrm{M}(17)$ ), followed by rinsing in distilled water, and then electropolished using one of the following typical experimental conditions:

- Potentiostatic control: Applied potential 20-21 V for 2-5 min in 61\% perchloric acid-95\% ethanol $(19 / 81, \mathrm{v} / \mathrm{v})$ at $2{ }^{\circ} \mathrm{C}(18,19)$.

- Galvanostatic control: Current density of $75 \mathrm{~mA} \mathrm{~cm}^{-2}$ (or $125 \mathrm{~mA} \mathrm{~cm}^{-2}$ (20)) in a $2: 3(\mathrm{v} / \mathrm{v})$ phosphoric/sulfuric acid solution in $1 \%$ glycerol at $70-80{ }^{\circ} \mathrm{C}(17)$.

According to Hornyak et al. (17), the electropolished aluminum is rinsed immediately in distilled water (often with the aid of a strong stream of distilled water to remove the tenacious gelatinous oxide layer), immersed in concentrated nitric acid for $10 \mathrm{~min}$, rinsed and left to dry in air. Well-polished aluminum should present a shiny/mirror-like surface; accurate polishing is crucial for obtaining high-quality aluminum oxide membranes.

The pre-treated aluminum is then anodized potentiostatically or galvanostatically in a thermostatically controlled bath $(14,16,21)$. Potentials from 10 to $160 \mathrm{~V}$ and current densities from 10 to $30 \mathrm{~mA} \mathrm{~cm}^{-2}$ are usually applied; however, for high pore spacing, voltages as high as $700 \mathrm{~V}$ have been used (22). The electrolyte is typically $15 \%$ sulfuric acid $\left(10{ }^{\circ} \mathrm{C}\right), 4 \%$ phosphoric acid $\left(24{ }^{\circ} \mathrm{C}\right), 2 \%$ oxalic acid $\left(24{ }^{\circ} \mathrm{C}\right)$, or $3 \%$ chromic acid $\left(38^{\circ} \mathrm{C}\right)$ (14); the temperature ranges from 38 to $0{ }^{\circ} \mathrm{C}$ and even lower $(18,23)$.

The cathode used for the anodization of aluminum consists of a large plate of aluminum, lead, platinum, or stainless steel.

As shown in Table 16.2.1, the pore diameter is proportional to the DC potential or the current density used. The thickness of the porous aluminum oxide increases linearly with

Table 16.2.1

Conditions used for the electrochemical preparation of nanoporous alumina membranes

\begin{tabular}{lll}
\hline Applied potential $(\mathrm{V})$ & Pore diameter $(\mathrm{nm})$ & Pore density $\left(\times 10^{9} \mathrm{~cm}^{-2}\right)$ \\
\hline 30 & $52^{a}$ & $30^{d}$ \\
20 & $32^{b}$ & $56^{d}$ \\
15 & $22^{b}$ & $83^{d}$ \\
10 & $16^{c}$ & \\
${ }^{a}$ In $4 \%$ oxalic acid, reference (17). & \\
${ }^{b}$ In 10\% sulfuric acid, reference (17). & \\
${ }^{c}$ In 15\% sulfuric acid, reference (17). & \\
${ }^{d}$ From reference (14). &
\end{tabular}






Figure 16.2.1 Pore density vs. pore diameter in alumina nanoporous membranes prepared in the three electrolytes indicated. Reproduced with permission from http://www.synkera.com/. (for colour version: see colour section at the end of the book).

the anodization time at a given voltage and temperature and can be adjusted from 0.1 to $10 \mu \mathrm{m}$. The pore spacing varies with the applied potential and the electrolyte $\mathrm{pH}$; the effect of the applied voltage on pore density for films formed in $15 \%$ sulfuric acid at $10{ }^{\circ} \mathrm{C}$ is presented in the last column of Table 16.2.1.

As shown in Figure 16.2.1, there is a bi-logarithmic linear relationship between the pore density and the pore diameter.

The growth of the oxide layer is such that it advances into the aluminum phase with simultaneous formation and dissolution of the oxide to form the pores. During the pore formation, the aluminum anode material is never directly exposed to the solution since it is always coated by a relatively thin $(10-100 \mathrm{~nm})$ non-porous insulating oxide layer called the "barrier layer" (see Figure 16.2.2A). Various procedures can be used to separate the unoxidized aluminum from the porous oxide layer $(14,24)$. The most widely used is the so-called voltage reduction sequence (VRS) developed by Furneaux et al. (22). VRS entails the stepwise reduction of the potential so that a progressive reduction of the pore diameter is produced at the bottom of the pore (see Figure 16.2.2).

After formation of this highly porous layer, the electrode is immersed into an acidic detachment solution, typically $25 \%$ sulfuric acid or phosphoric acid, which causes the rapid dissolution of the interfacial oxide. This process is faster in the areas indented by the smaller and smaller branched pores. Under such conditions, the acid can readily access the $\mathrm{Al}$ electrode so that $\mathrm{H}_{2}$ gas is evolved; when the $\mathrm{H}_{2}$ bubbles coalesce, the process is completed. The $\mathrm{Al}$ electrode is then rinsed by immersion in water and dried in air. The porous alumina membrane is finally collected by sliding an index card between the alumina layer and the $\mathrm{Al}$ electrode. The two faces of the detached alumina membrane are not equivalent; the face that was detached from the $\mathrm{Al}$ electrode surface contains remnants of the interfacial oxide layer. However, these remnants can be 


\section{$\mathbf{A}$}

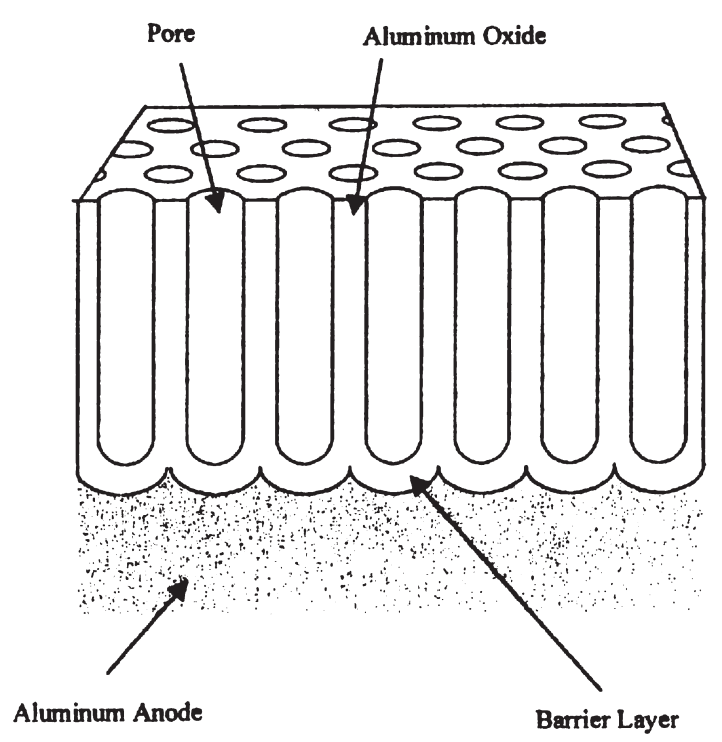

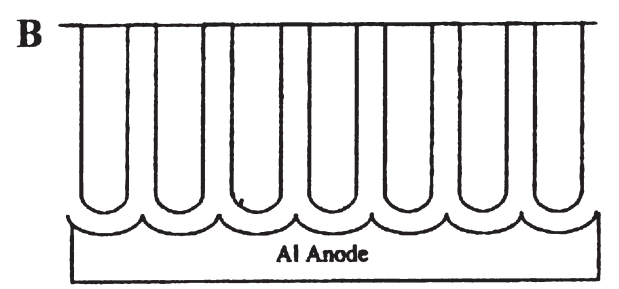
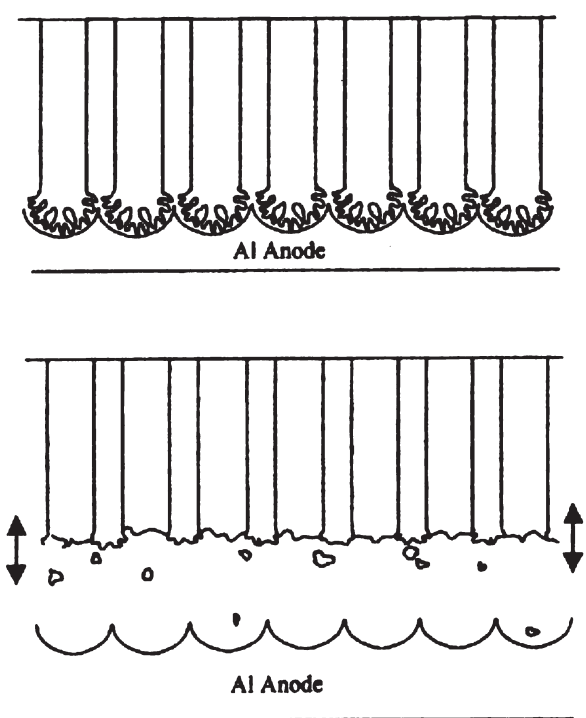

Figure 16.2.2 (A) Schematic drawing of the porous anodic aluminum oxide layer that is formed during aluminum anodization. (B) Steps involved in the detachment of the aluminum oxide layer from bulk aluminum by using the voltage reduction sequence. Top: growth of the primary pores; middle: voltage reduction and infiltration of barrier layer by branched pore network; bottom: dissolution of branched network region of the porous film and separation from aluminum anode. Reproduced with permission from reference (25).

removed by floating the membrane on the surface of a $0.2 \mathrm{M} \mathrm{KOH}$ solution in ethylene glycol. Such a procedure tends to make both faces of the membrane essentially equivalent (17). Another procedure to separate the porous film from the $\mathrm{Al}$ electrode is by immersing the anodized foil in a saturated aqueous $\mathrm{HgCl}_{2}$ solution. This results in the amalgamation of aluminum along the $\mathrm{Al}_{2} \mathrm{O}_{3} / \mathrm{Al}$ interface and delamination of the oxide layer. The remaining part of the insulating barrier layer is then etched away with $0.025 \mathrm{M}$ $\mathrm{NaOH}$ solution (26).

Note that both of these approaches induce isotropic chemical etching with concomitant enlargement of pore size. Very recently, Mallouk and coworkers (20) proposed a new method to penetrate and detach the barrier layer by applying a reverse bias voltage $(-3.5$ to $-5 \mathrm{~V}$ ) immediately after the completion of the anodization; both anodization and reverse bias are carried out in the same $3 \% \mathrm{H}_{2} \mathrm{SO}_{4}$ solution. When $\mathrm{H}_{2}$ bubbles are observed, the bias voltage is reduced until no more bubbles are detected; the process takes a few minutes. It was postulated (20) that the application of a reverse bias voltage in acidic 
solution results in an increase of the local $\mathrm{H}^{+}$concentration, thus promoting the dissolution of the oxide barrier layer by the following reaction:

$$
\mathrm{Al}_{2} \mathrm{O}_{3}(\mathrm{~s})+6 \mathrm{H}^{+}(\mathrm{aq}) \rightarrow 2 \mathrm{Al}^{3+}(\mathrm{aq})+3 \mathrm{H}_{2} \mathrm{O}(\mathrm{l})
$$

The reverse bias method was applied successfully to both bulk aluminum and thin aluminum layers deposited on $\mathrm{Ti} / \mathrm{Si}_{x} \mathrm{O} / \mathrm{Si}$ wafers (20).

Recently, Mozalev et al. (27) detached the alumina film from the residual aluminum foil by dipping in an $\mathrm{HCl}-\mathrm{CuCl}_{2}$ solution, until the aluminum metal was completely dissolved. The pores of the alumina film were protected with gelatine gel and the oxide barrier layer was finally dissolved with $5 \% \mathrm{NaOH}$ from the bottom side of the film. This method allows the complete removal of the barrier layer without introducing discontinuities in the pore network across the membrane.

Freestanding alumina microporous membranes are commercially available, for example, from Anopore ${ }^{\mathrm{TM}}$ or Synkera Technologies Inc. The rather limited number of pore sizes available limits a wider use of the commercial alumina membranes as templates so that many research groups still prefer to prepare their own membranes.

\subsubsection{Track-etched polymer membranes}

Nanoporous polymeric membranes can be prepared by the track-etch method. This method involves tracking a film of solid material (polymer) with a beam of high-energy particles to create damage tracks in the film. Such tracks are then etched into monodisperse pores by exposure to an alkaline etching solution. The time the material is exposed to the tracking particles determines the number of tracks (and thus pores), while the etching time (as well as the composition of the etching solution) determines the size of the pores $(28,29)$.

Polymeric materials used for the production of track-etched membranes include poly(ethylene terephthalate) (PET), polycarbonate (PC), polyimide (Kapton), polypropylene, polyvinylidene fluoride, and CR-39 (allyl diglycol carbonate) (29). The most widely used are PET, PC, and Kapton.

PET presents a high etch ratio that allows the production of membranes with a wide range of pore diameters. The membranes are relatively hydrophilic, rather stable to acids and organic solvents, and biologically inert. However, PET-tracked membranes require UV irradiation before etching. The membrane is exposed to UV light with maximum intensity at $320 \mathrm{~nm}$ for approximately $30 \mathrm{~min}$. The UV treatment leads to saturation of the damage in the tracks so that further storage of the samples in air or illumination with visible light does not change the etching behavior (30).

$\mathrm{PC}$ is the material used for preparing the majority of commercially available tracketched membranes. It is characterized by high sensitivity to tracking and it does not require UV sensitization. However, PC is soluble in organic solvents and has low wettability in aqueous solutions. Its hydrophilicity can be increased by impregnation with polyvinylpyrrolidone (29).

Kapton foils are also used to produce nanoporous track-etched membranes $(31,32)$. Track-etched membranes are commercially available as filtration membranes with pore 
diameters ranging from as small as $10 \mathrm{~nm}$ to as large as $10 \mu \mathrm{m}$ and pore densities between $10^{7}$ and $10^{9}$ pores $\mathrm{cm}^{-2}$. Track but not etched nanoporous membranes are also commercially available, for example, from Osmonics $\left(50\right.$ tracks $\left.\mathrm{cm}^{-2}\right)$ or from Whatman $\left(10^{7}\right.$ tracks $\left.\mathrm{cm}^{-2}\right)$.

\section{(a) Tracking}

There are two basic methods of producing latent tracks in the polymer foils to be transformed into porous membranes. The first method is based on the irradiation with fragments from the fission of heavy nuclei such as californium, bismuth, or uranium (33) of energy $11.4 \mathrm{MeV}$ per nucleon $(30,34)$. Typical energy losses of the fission fragments are about $10 \mathrm{keV} \mathrm{nm}^{-1}$. The fission fragments coming from a thin layer target have an almost isotropic angle distribution. To create an array of latent tracks penetrating the foil, a collimator is normally used. The advantages of this tracking method are: (a) good time stability of the particle flux and (b) relatively low cost. The limitations of the method are: (a) contamination of the tracked foil with radioactive products ("cooling" of the irradiated material is needed, which usually takes few months); (b) limited thickness of the membrane to be tracked; (c) limited possibilities of controlling the angle distribution of the tracks; (d) fragments of different masses and energies produce tracks with different etching properties (29).

The second method is based on the use of ion beams in accelerators (29). The intensity of the ion beam should be at least $10^{11} \mathrm{sec}^{-1}$. To irradiate large areas, a scanning beam is normally used. The advantages of the ion beam accelerator tracking method are: (a) no radioactive contamination of the material when the ion energy is below the Coulomb barrier; (b) identity of the bombarding particles gives tracks with the same etching properties; (c) large range of high-energy particles makes possible the tracking of thicker membranes; (d) better conditions for producing high-density $\left(>10^{9} \mathrm{~cm}^{-2}\right.$ ) track arrays; (d) particles heavier than fission fragments can be used $\left({ }^{238} \mathrm{U}\right.$, for example); (e) it is easier to control the impact angle and produce arrays of parallel tracks or create some particular angular distributions for getting rid of merging pores (29).

Very recent advances have shown that it is possible to control the number and the geometric distribution of tracks with an ion beam (35). The sample is covered by a metallic mask with a hole of small diameter $(0.1 \mathrm{~mm})$ so that the ions can penetrate the film only within a small area. By registering the ions passing through the film and shutting down and moving the membrane after one single ion has passed through $(31,34)$, it is possible to obtain single pore membranes or membranes with geometrically patterned arrays of tracks (and pores). The limitations of the ion beam accelerator method are: (a) relative instability of the particle flux and (b) higher cost than irradiation.

In the past decade, a decrease in the popularity of reactor-based irradiation facilities and an increase in the use of accelerated ion beams were observed (29). With the use of ion beams from accelerators, it is easier to control the impact angle for getting rid of merging pores of the kind shown in Figure 16.2.3A (29).

\section{(b) Chemical etching}

Chemical etching is the process of pore formation during which the damaged zone of a latent track is removed and transformed into a hollow channel (pore) $(29,33)$. The most 

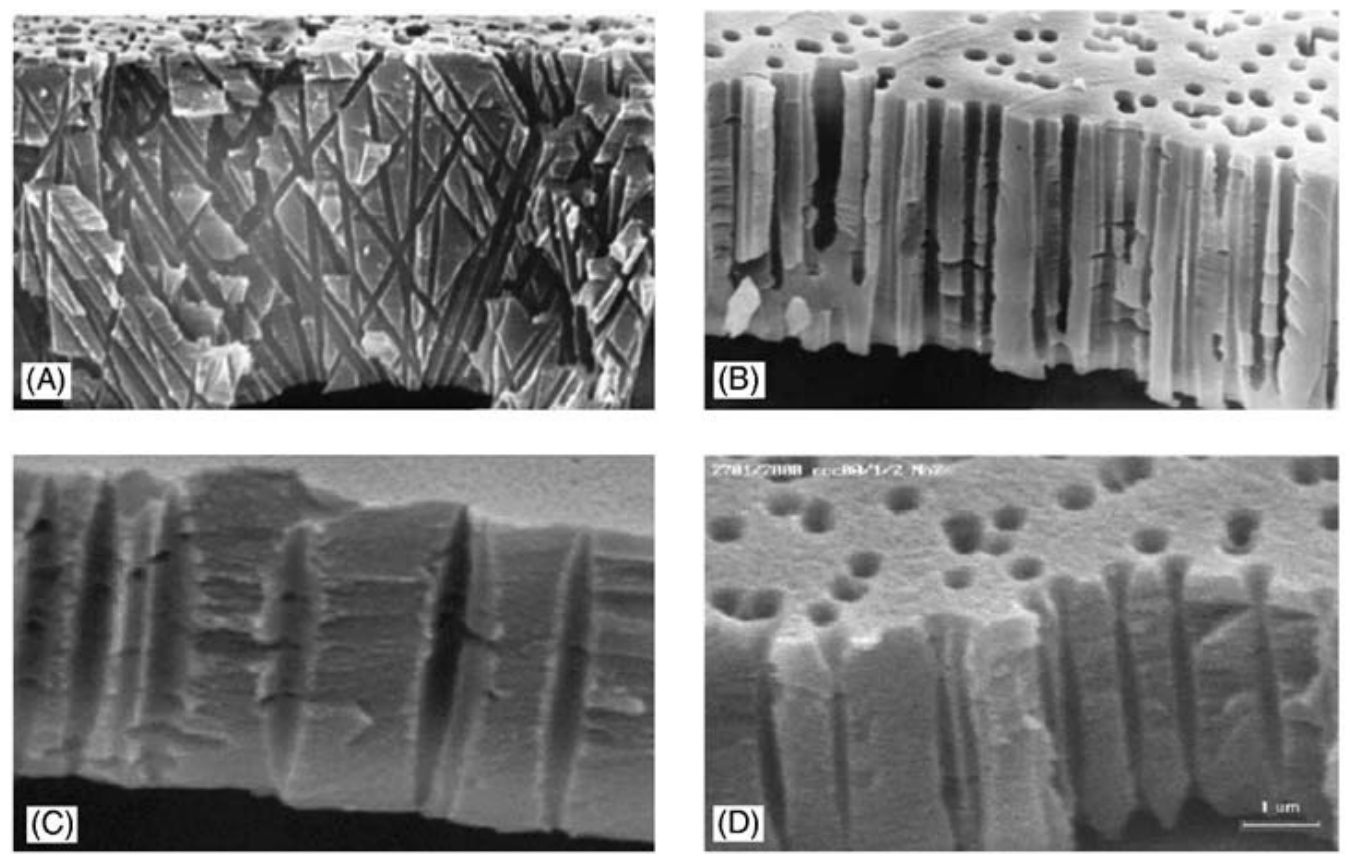

Figure 16.2.3 Porous structures produced in thin polymeric films using various methods of irradiation and chemical treatment: (A) cross-section of a polycarbonate membrane with cylindrical nonparallel pore channels; (B) polypropylene with slightly conical (tapered toward the center) parallel pores; (C) poly(ethylene terephthalate) with cigar-like pores; (D) poly(ethylene terephthalate) with "bow-tie" pores. Reprinted with permission from reference (29).

widely used etching agents are alkali solutions $(\mathrm{KOH}$ or $\mathrm{NaOH})$ although the etching of polyimide (Kapton) requires an oxidizing agent such as $\mathrm{NaClO}(31,32)$. The simplest description of the kinetics of the etching process is based on two parameters: the bulk etch rate $\left(V_{\mathrm{B}}\right)$ and the track-etch rate $\left(V_{\mathrm{T}}\right)$. While $V_{\mathrm{B}}$ depends on the material, the etchant composition, and the temperature, $V_{\mathrm{T}}$ depends on additional parameters such as sensitivity of the material, irradiation, post-irradiation conditions, and etching conditions (29). Etching with $\mathrm{KOH}$ or $\mathrm{NaOH}$ on both sides of the tracked membrane generates pores with a symmetric shape that are typically cylindrical or cigar-like (see Figure 16.2.3).

The formation of cigar-like-shaped pores has been explained by two hypotheses (36): (a) further exposure by electrons generated in the secondary electron cascade caused by the impact of the high-energy particle and (b) an acceleration of the etching rate caused by the etching products, which are more concentrated inside the pores. It was shown that perfectly cylindrical pores could be obtained if a special PC film $\left(\mathrm{PC}^{+}\right)$is used instead of standard PC films (36).

It was recently shown that strict control of the etching conditions allows one to control the shape of the pores, obtaining, for example, funnel-like or conically shaped pores (30). Conical pores can be obtained by asymmetric etching with oxygen plasma of initially cylindrical pores (37), or by performing an asymmetric chemical etching, so that $V_{\mathrm{B}}>V_{\mathrm{T}}$, with the ratio changing throughout the thickness of the membrane. Asymmetric etching of 




Figure 16.2.4 (A) Scheme of the experimental set-up with the etching cell for asymmetric pore etching. (B) Direction of electromigration and diffusion during break-through under stopping electric field conditions (30). $(\rightarrow)$ Migration and $(\sim>)$ diffusion direction. Adapted with permission from references $(30,34)$.

tracked membranes was first described three decades ago (38). It is based on the treatment of an ion-irradiated sample with an etchant on one side, while the opposite face is in contact with a stopping medium that neutralizes the etchant as soon as it perforates the sample. This method was modified recently by applying an additional electric field (34). The application of the electric field allows one to detect the instant of pore break-through and, additionally, to protect the etched cone pore from further chemical attack. The scheme of the apparatus used for the asymmetric etching is shown in Figure 16.2.4A.

For asymmetric etching of PC or PET, one side of the membrane is put in contact with an alkaline etching solution, usually $9 \mathrm{M} \mathrm{NaOH}$ or $\mathrm{KOH}$, and the other side is in contact with the stopping medium, typically a weak acid solution such as $1 \mathrm{M} \mathrm{HCOOH}$ in $1 \mathrm{M}$ $\mathrm{KCl}$ (30). For asymmetric etching of polyimide (Kapton), the etching solution is $\mathrm{NaClO}$ 
(with $13 \%$ active chlorine) while the stopping medium is a suitable reducing agent such as $1 \mathrm{M} \mathrm{KI}$ (39). A potential of some tens of volts is applied across the membrane by two Pt electrodes. As shown in Figure 16.2.4A, a positive potential is applied to the electrode in the etching solution, while the electrode in the stopping solution is at a negative potential. As shown in Figure 16.2.4B, if a positive potential is applied from the alkali (etchant) side during the break-through, the $\mathrm{OH}^{-}$anions are pulled out of the pore which accelerates the stopping process. It was demonstrated (30) that electrostopping at voltages around $1 \mathrm{~V}$ is more efficient in producing conical pores than chemical stopping alone.

The application of a potential across the membrane is stopped as soon as a monitoring ammeter records an increase in the current that passes through the membrane up to reaching a pre-set value, typically $1 \mathrm{~mA}(40)$. The membrane is then immediately immersed (both sides) in the stopping medium, thus blocking the asymmetric etching. At the end of the process, conical nanopores of controlled shape are obtained $(37,40)$. It was also shown that the addition of alcohols (such as methanol, ethanol, or propanol) to the etch solution allows further control of the etching rate (24) and the $V_{\mathrm{B}} / V_{\mathrm{T}}$ ratio $(40,41)$.

\subsubsection{Comparison between alumina and track-etched polymer nanoporous membranes}

Track-etched membranes are flexible with a smooth surface while alumina films are brittle and rather rough. Another difference is the pore density which is typically $10^{9}$ pores $\mathrm{cm}^{-2}$ for track-etched membranes compared to $10^{11}$ pores $\mathrm{cm}^{-2}$ for alumina membranes (42). Alumina membranes are therefore interesting as templates for producing high-density nanomaterials. Track-etched membranes are more suitable for obtaining low-density nanomaterials, for example, in the fabrication of NEEs where low nanoelectrode densities are often desired. As shown in Figure 16.2.3, a problem with track-etched membranes is the fact that the pores are not always parallel to each other. Their shape is not always cylindrical and pore positions are randomly distributed unless special procedures are applied (43). For alumina membranes, depending on the method used to separate the membrane from the aluminum, the pores on the side of the barrier layer can be branched into smaller pores (see Figure 2 in reference (44)).

\subsubsection{Template deposition of metals}

\subsubsection{Electrochemical deposition}

Electrochemical deposition of metals in the pores of templating membranes requires that one side of the membrane be in direct contact with a metallic layer. This can be produced by plasma or vacuum deposition of a metal layer on one side of the membrane (25) and requires that the membrane film be robust enough to tolerate this kind of manipulation. The thickness of the conductive layer is typically $100-1000 \mathrm{~nm}$ (45-47). The metal which produces the conductive layer can be the same or different from the one that will provide the final template structure. In electrochemical template deposition, the coated film is placed in an electrochemical cell where the template membrane acts as the cathode and a counter electrode is the anode. The deposition can be carried out under galvanostatic or 
potentiostatic conditions. In the case of track-etched PC, it was recently shown that the addition of $1-2 \%$ gelatin to the plating solution improves the wettability of the nanoporous membrane, thus improving the reproducibility of the electrodeposition step $(45,48-50)$.

Final products of the electrochemical deposition are solid nanoparticles, typically nanowires and not hollow structures (e.g., nanotubes or nanocapsules). The electrochemical process is based on the progressive growth and filling of the pores starting from the bottom metallic layer and proceeding progressively toward the open end of the templating pore.

Figure 16.2.5B summarizes the steps for electrochemical growth of continuous metal wires for use as micro- or nanoelectrodes, for example. To form smaller template nanoparticles or nanowire segments, procedure 1-2-5-6 is used. For this latter case, sputtering and

A)

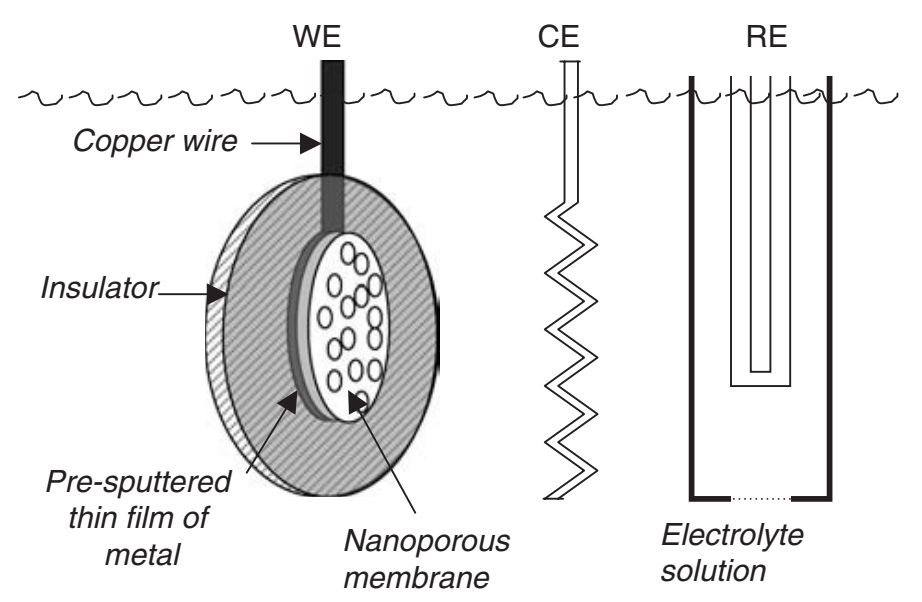

B)

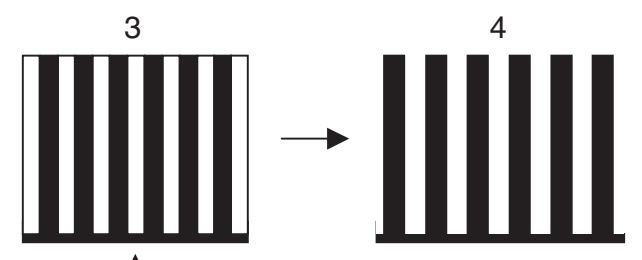

1

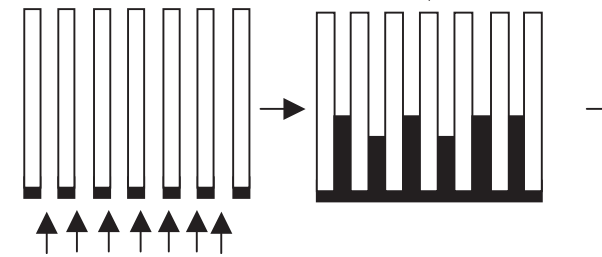

5 
the first growth of nanowires are performed with an etchable metal such as silver which acts as a foundation for the deposition of the metal of interest to be deposited in a desired amount in a second step as shown in Figure 16.2.5B-5 (15). The silver foundation is then etched away with nitric acid leaving the nanoparticles or nanowire segments composed of the second metal (gold, for example) in the pores of the template (Figure 16.2.5B-6). A similar procedure is also used for fabricating multilayered nanowires composed of cylindrical segments of different metals such as $\mathrm{Ni} / \mathrm{Cu}(51), \mathrm{Co} / \mathrm{Cu}(52)$, or $\mathrm{Au} / \mathrm{Sn}(50)$. Table 16.2.2 summarizes examples of template electrochemical deposition of nanowires, nanoparticles, or nanowire segments.

\subsubsection{Electroless deposition of metals}

Electroless metal deposition involves the use of chemical reducing agents to plate a metal from a solution onto a surface (68). The key requirement for this process is to arrange the chemistry so that the kinetics of homogeneous electron transfer from the reducing agent to the metal ion is very slow. A catalyst that accelerates the rate of metal ion reduction is then applied to the surface to be coated. In this way, the metal ion is reduced at the surface incorporating the catalyst so that only this surface is coated with the desired metal. The thickness of the metal film deposited can be controlled by changing the plating time (7).

The principles of electroless deposition in templates are exemplified for Au deposition developed in Martin's laboratory for the template fabrication of NEEs, nanotubes, and other shaped gold nanomaterials $(5,7)$. The electroless plating of gold (5) consists of three steps: (i) "sensitization" with $\mathrm{Sn}^{2+}$; (ii) reduction of $\mathrm{Ag}^{+}$to produce discrete $\mathrm{Ag}$ metal nanoparticles; (iii) galvanic displacement of Ag particles by reduction of gold followed by auto-catalytic reduction of more Au.

Detailed conditions for Au electroless deposition include (5, 69):

(i) After wetting for $2 \mathrm{~h}$ in methanol, the PC membrane is sensitized with $\mathrm{Sn}^{2+}$ by immersion into a solution $0.026 \mathrm{M}$ in $\mathrm{SnCl}_{2}$ and $0.07 \mathrm{M}$ in trifluoroacetic acid in 50:50 methanol/water as the solvent for $45 \mathrm{~min}$.

(ii) After rinsing with methanol for $5 \mathrm{~min}$, the sensitized membrane is immersed for 10 min in $50 \mathrm{~mL}$ of $0.029 \mathrm{M} \mathrm{Ag}\left[\left(\mathrm{NH}_{3}\right)_{2}\right] \mathrm{NO}_{3}$. This solution is prepared by a dropwise addition of concentrated $\mathrm{NH}_{4} \mathrm{OH}$ from a burette ( $1 \mathrm{~mL}$ or less will be needed) to a $0.029 \mathrm{M} \mathrm{AgNO}_{3}$ aqueous solution. With a careful, dropwise addition, a brown precipitate will appear and then disappear with further addition of $\mathrm{NH}_{4} \mathrm{OH}$. At the first disappearance of the brown precipitate, the $\mathrm{Ag}\left[\left(\mathrm{NH}_{3}\right)_{2}\right] \mathrm{NO}_{3}$ solution is ready.

(iii) The membrane is then immersed into an Au plating bath (volume $\sim 20 \mathrm{~mL}$ ) composed of $7.9 \times 10^{-3} \mathrm{M} \mathrm{Na}_{3} \mathrm{Au}\left(\mathrm{SO}_{3}\right)_{2}, 0.127 \mathrm{M} \mathrm{Na}_{2} \mathrm{SO}_{3}$, and approximately $0.6 \mathrm{M}$ formaldehyde ( $1 \mathrm{~mL}$ of formaldehyde $37 \%$ solution in water is added); the $\mathrm{pH}$ of the plating bath is around 11-11.5 for nanowires, which is lowered to 8 for nanotubes (see below). Note that the Au electroless bath component is typically obtained by 1:40 dilution of commercial plating baths, such as Oromerse SO Part B (Technic Inc.) which contains 0.4 troy ounces of gold in $200 \mathrm{~mL}$ (1 troy ounce $=31.1035 \mathrm{~g}$ of gold), that is, $0.316 \mathrm{M}$ in $\mathrm{Na}_{3} \mathrm{Au}\left(\mathrm{SO}_{3}\right)_{2}$ (5).

(iv) After $15 \mathrm{~h}$ of electroless deposition, an additional $0.2 \mathrm{~mL}$ of formaldeheyde is added. 
Table 16.2.2

Conditions and materials used for the electrochemical template deposition of metals

\begin{tabular}{|c|c|c|c|c|c|}
\hline $\begin{array}{l}\text { Metal } \\
\text { deposited }\end{array}$ & $\begin{array}{l}\text { Templating } \\
\text { membrane }\end{array}$ & Electrodeposition conditions & Nanomaterial obtained & Note & References \\
\hline $\mathrm{Au}$ & $\begin{array}{l}\text { Mica } \\
\text { (track-etched) }\end{array}$ & $\begin{array}{l}\text { Commercial } \mathrm{Au} \text { electroplating solution, } \mathrm{pH}=6, \\
T=60^{\circ} \mathrm{C} \text {, potential step up to a constant current } \\
\text { value, or } \mathrm{Au}-\mathrm{Ag} \text { alloys electroplating solution, } \\
\mathrm{pH}=8-9\end{array}$ & $\begin{array}{l}\text { Wires }(\phi=8 \mathrm{~nm} \text { for } \\
\text { commercial bath and } \\
20 \mathrm{~nm} \text { for } \mathrm{Au}-\mathrm{Ag} \\
\text { alloy bath) }\end{array}$ & & (2) \\
\hline $\mathrm{Au}$ & Alumina & $\begin{array}{l}\text { Commercial electroless bath (Orotemp } 24 \text {, } \\
\text { Technic Inc.), galvanostatic }\left(0.8-1.2 \mathrm{~mA} / \mathrm{cm}^{2}\right) \text {, } \\
\text { two-compartment cell }\end{array}$ & $\begin{array}{l}\text { Wires (microhole array); } \\
\phi \sim 200 \mathrm{~nm}\end{array}$ & & $(53)$ \\
\hline
\end{tabular}

$\mathrm{Au}$

Alumina

$0.32 \mathrm{M} \mathrm{Au}(\mathrm{I})$ cyanide, $0.26 \mathrm{M}$ citric acid, $0.65 \mathrm{M} \mathrm{KOH}, \mathrm{pH}=5-6$, potentiostatic

Nanorods, $\phi=12-22 \mathrm{~nm}$

$\mathrm{Au}$

Alumina

$12 \mathrm{~g} / \mathrm{L} \mathrm{HAuCl}_{4}, 160 \mathrm{~g} / \mathrm{L} \mathrm{Na}_{2} \mathrm{SO}_{3}, 5 \mathrm{~g} / \mathrm{L}$ EDTA $30 \mathrm{~g} / \mathrm{L} \mathrm{K}_{2} \mathrm{HPO}_{4}, 0.5 \mathrm{~g} / \mathrm{L} \mathrm{CoSO}_{4}, \mathrm{pH}=9.0$, potentiostatic, $0.8 \mathrm{~V}$

$\mathrm{Au}$

Polycarbonate $0.32 \mathrm{M}$ gold(I)cyanide $+0.26 \mathrm{M}$ citric acid,

$0.65 \mathrm{M} \mathrm{KOH}, \mathrm{pH}=5-6$, potentiostatic:

$-1.0 \mathrm{~V}$ vs. SCE

$\mathrm{Au}$

Alumina

Commercial Au electrodeposition bath (Orotemp Technic Inc.); deposition at $-2.5 \mathrm{~V}$

$\mathrm{Au}, \mathrm{Ag}, \quad$ Polycarbonate

$\mathrm{Cu}, \mathrm{Ni}$,

$\mathrm{Co}, \mathrm{Rh}$

$\mathrm{Co}$

Crystalline

bisphenol-A polycarbonate
Electrodeposition from suitable baths added with $1-2 \%$ gelatin to improve polycarbonate wettability

$\mathrm{CoSO}_{4}$ bath, three-electrode cell, room temperature $(\phi<10 \mathrm{~nm})$

length $=39-729 \mathrm{~nm}$

Wires

Wire diameter even

three times the nominal

diameter of the

membrane

Electrodeposition

takes advantage of

penetration of aluminum oxide barrier layer by reverse bias voltage

$\mathrm{Au}, \mathrm{Ag}, \mathrm{Cu}$ single-

crystalline nanowires;

$\mathrm{Ni}, \mathrm{Co}, \mathrm{Rh}$ polycrystalline nanowires

Wires, $\phi=70$ and Wires "toothpick"

$10 \mathrm{~nm}$

shape 
Table 16.2.2 (Cont.)

\begin{tabular}{|c|c|c|}
\hline $\begin{array}{l}\text { Metal } \\
\text { deposited }\end{array}$ & $\begin{array}{l}\text { Templating } \\
\text { membrane }\end{array}$ & Electrodeposition conditions \\
\hline $\mathrm{Co}$ & Alumina & $\begin{array}{l}40 \mathrm{~g} / \mathrm{L} \mathrm{CoSO} \mathrm{Co}_{4} \cdot \mathrm{H}_{2} \mathrm{O}, 40 \mathrm{~g} / \mathrm{L} \mathrm{H}_{3} \mathrm{BO}_{3}, \\
20 \mathrm{~g} / \mathrm{L} \text { ammonium citrate, } \mathrm{pH}=3.5, T=50{ }^{\circ} \mathrm{C} \text {, } \\
\text { current density: } 0.3-0.8 \mathrm{~mA} / \mathrm{cm}^{2} \text {, two-electrode } \\
\text { cell }\end{array}$ \\
\hline $\mathrm{Co}$ & Polycarbonate & $\begin{array}{l}400 \mathrm{~g} / \mathrm{L} \mathrm{CoSO}{ }_{4} \cdot 7 \mathrm{H}_{2} \mathrm{O}+40 \mathrm{~g} / \mathrm{L} \mathrm{H}_{3} \mathrm{BO}_{3}, \\
\text { potentiostatic: }-1.1 \mathrm{~V} \text { vs. Saturated Calomel } \\
\text { Electrode }\end{array}$ \\
\hline Co & Polycarbonate & $\begin{array}{l}0.1 \mathrm{M} \mathrm{H}_{3} \mathrm{BO}_{3}+5 \times 10^{-2} \mathrm{M} \mathrm{CoSO}_{4} \\
\text { potentiostatic, applying a sequence of pulses } \\
(-1.3 \text { and }-0.8 \mathrm{~V}), \text { three-electrode cell }\end{array}$ \\
\hline $\mathrm{Co}$ & Polycarbonate & $\begin{array}{l}0.1 \mathrm{M} \mathrm{H}_{3} \mathrm{BO}_{3}+0.1 \mathrm{M} \mathrm{CoSO}_{4} \text {, potentiostatic, } \\
\text { applying a sequence of pulses }(-1.5 \text { and } \\
-0.8 \mathrm{~V}), \text { three-electrode cell }\end{array}$ \\
\hline $\mathrm{Co}$ & Polycarbonate & $\begin{array}{l}20 \mathrm{~g} / \mathrm{L} \mathrm{H}_{3} \mathrm{BO}_{3}+252 \mathrm{~g} / \mathrm{L} \mathrm{CoSO}_{4} \cdot 7 \mathrm{H}_{2} \mathrm{O}+ \\
7 \mathrm{~g} / \mathrm{L} \mathrm{NaCl}, \mathrm{pH}=3.6, \text { potentiostatic }\end{array}$ \\
\hline $\mathrm{Cu}$ & Polycarbonate & $\begin{array}{l}0.6 \mathrm{M} \mathrm{CuSO}_{4}+\mathrm{H}_{2} \mathrm{SO}_{4}(\mathrm{pH}=2) \\
\text { potentiostatic, }-0.4 \mathrm{~V} \text { vs. } \mathrm{Cu} \text { ref. }\end{array}$ \\
\hline $\mathrm{Cu}$ & Polycarbonate & $\begin{array}{l}125 \mathrm{~g} / \mathrm{L} \mathrm{CuSO}_{4} \cdot 5 \mathrm{H}_{2} \mathrm{O}+\mathrm{H}_{2} \mathrm{SO}_{4} \text { up to } \mathrm{pH}=1.0 \\
\text { potentiostatic: }-0.2 \mathrm{~V} \text { vs. } \mathrm{SCE}\end{array}$ \\
\hline $\mathrm{Fe}$ & Polycarbonate & $\begin{array}{l}0.1 \mathrm{M} \mathrm{H}_{3} \mathrm{BO}_{3}+5 \times 10^{-2} \mathrm{M} \mathrm{FeSO}_{4} \text {, } \\
\text { potentiostatic, applying a sequence of pulses } \\
(-1.3 \text { and }-0.8 \mathrm{~V}), \text { three-electrode cell }\end{array}$ \\
\hline $\mathrm{Fe}$ & Polycarbonate & $\begin{array}{l}0.1 \mathrm{M} \mathrm{H}_{3} \mathrm{BO}_{3}+0.1 \mathrm{M} \mathrm{FeSO}_{4} \text {, potentiostatic, } \\
\text { applying a sequence of pulses }(-1.3 \mathrm{~V} / 0.1 \mathrm{sec} \text {, } \\
\text { cell off } / 2 \mathrm{sec}) \text {, three-electrode cell }\end{array}$ \\
\hline $\mathrm{Ni}$ & Alumina & $\begin{array}{l}270 \mathrm{~g} / \mathrm{L} \mathrm{NiSO} \cdot 7 \mathrm{H}_{2} \mathrm{O}, 40 \mathrm{~g} / \mathrm{L} \mathrm{NiCl}{ }_{2} \cdot \mathrm{H}_{2} \mathrm{O}, 40 \mathrm{~g} / \mathrm{L} \\
\mathrm{H}_{3} \mathrm{BO}_{3}, \mathrm{pH}=3.6, T=50^{\circ} \mathrm{C} \text {, current density: } \\
0.3-0.8 \mathrm{~mA} / \mathrm{cm}^{2}\end{array}$ \\
\hline
\end{tabular}

Nanomaterial obtaine

three times the nominal

pore diameter

Cigar-shaped

monocrystalline

wires $(\phi \approx 60 \mathrm{~nm})$

Wires or nanotubes

The nanotubes are obtained changing the pulse cycles

Arrays of nanowires

Wires

Wires

\section{Cigar-shaped}

monocrystalline wires

or tubes $(\phi \approx 60 \mathrm{~nm})$

Nanotubes

"Foundation" film

of Pt-Pd

Wire diameter even

three times the nominal pore diameter

Short deposition time produced mainly nanotubes 


\begin{tabular}{|c|c|c|}
\hline $\mathrm{Ni}$ & Alumina & $\begin{array}{l}300 \mathrm{~g} / \mathrm{L} \mathrm{NiSO}_{4} \cdot 6 \mathrm{H}_{2} \mathrm{O}, 45 \mathrm{~g} / \mathrm{L} \mathrm{NiCl} \mathrm{Ni}_{2} \cdot 6 \mathrm{H}_{2} \mathrm{O} \\
45 \mathrm{~g} / \mathrm{L} \mathrm{H}_{3} \mathrm{BO}_{3}, \mathrm{pH}=4.5, T=35{ }^{\circ} \mathrm{C} \text {, constant } \\
\text { current pulses }\end{array}$ \\
\hline $\mathrm{Ni}$ & Polycarbonate & $\begin{array}{l}515 \mathrm{~g} / \mathrm{L} \mathrm{Ni}\left(\mathrm{H}_{2} \mathrm{NSO}_{3}\right)_{2} \cdot 4 \mathrm{H}_{2} \mathrm{O}+20 \mathrm{~g} / \mathrm{L} \\
\mathrm{NiCl}_{2} \cdot 6 \mathrm{H}_{2} \mathrm{O}+20 \mathrm{~g} / \mathrm{L} \mathrm{H}_{3} \mathrm{BO} \\
\text { potentiostatic: }-1.2 \mathrm{pH}=3.4,\end{array}$ \\
\hline $\mathrm{Pd}$ & Alumina & $\begin{array}{l}1 \times 10^{-3} \mathrm{M}\left(\mathrm{NH}_{4}\right)_{2} \mathrm{PdCl}_{4}+50 \mathrm{mM} \mathrm{LiCl}+ \\
50 \mathrm{mM} \mathrm{LiSO}_{4}, \text { four-electrode mode }\end{array}$ \\
\hline $\mathrm{Pt}$ & Alumina & $\begin{array}{l}1 \times 10^{-3} \mathrm{M} \text { ammonium tetrachloroplatinate }+ \\
50 \mathrm{mM} \mathrm{LiCl}+50 \mathrm{mM} \mathrm{LiSO}_{4} \text {, four-electrode } \\
\text { mode }\end{array}$ \\
\hline Sn & Polycarbonate & $\begin{array}{l}0.1 \mathrm{M} \mathrm{Sn}_{2} \mathrm{SO}_{4}+2 \% \text { gelatin, } \mathrm{pH}=1 \\
\text { with } \mathrm{H}_{2} \mathrm{SO}_{4}, E_{\text {applied }}=-80 \mathrm{mV}\end{array}$ \\
\hline Sn & Alumina & $\begin{array}{l}7 \mathrm{~g} / \mathrm{L} \mathrm{SnCl} \cdot 2 \mathrm{H}_{2} \mathrm{O}+25 \mathrm{~g} / \mathrm{L} \mathrm{Na}_{3} \mathrm{C}_{6} \mathrm{H}_{5} \mathrm{O}_{7} \cdot 2 \mathrm{H}_{2} \mathrm{O} \\
\text { potentiostatic, }-0.8 \mathrm{~V} \text { (vs. Ag/AgCl saturated), } \\
\text { Sn wires annealed in the air give } \mathrm{SnO}_{2} \text { wires }\end{array}$ \\
\hline $\mathrm{Au} / \mathrm{Sn}$ & Polycarbonate & $\begin{array}{l}\text { Sequential electrodeposition of Au and Sn using } \\
\text { conditions as in references }(20,45) \text { for Au and } \\
\text { reference (48) for Sn }\end{array}$ \\
\hline $\mathrm{Bi}_{2} \mathrm{Te}_{3}$ & Alumina & $\begin{array}{l}\mathrm{HTeO}_{2}+25 \mathrm{mM}, \mathrm{Bi}\left(\mathrm{NO}_{3}\right)_{3} \cdot 5 \mathrm{H}_{2} \mathrm{O} 33 \mathrm{mM} \text {, } \\
\text { galvanostatic deposition, } 3.5 \mathrm{~mA} / \mathrm{cm}^{2}\end{array}$ \\
\hline $\mathrm{Bi}_{2} \mathrm{Te}_{3}$ & Alumina & $\begin{array}{l}1 \mathrm{M} \mathrm{HNO}_{3}+\text { elemental Bi and Te, } \\
\text { three-electrode cell, potentiostatic } \\
\left(E<-0.45 \mathrm{~V} \text { vs. } \mathrm{Hg} / \mathrm{Hg}_{2} \mathrm{SO}_{4}\right)\end{array}$ \\
\hline
\end{tabular}

Wires, magnetic material

Wires

Nanoparticles $(\phi \approx 3-5 \mathrm{~nm})$

Nanoparticles $(\phi \approx 3-5 \mathrm{~nm})$

Single crystal nanowires

$\mathrm{Sn}$ and $\mathrm{SnO}_{2}$

nanowires array

Striped $\mathrm{Au} / \mathrm{Sn} / \mathrm{Au}$

nanowires

Nanowires

Wires
Wire diameter even

three times the nominal pore diameter

Deposition at the polarized interface between aqueous solution and 1,2-dichloroethane

Deposition at the polarized interface between aqueous

solution and

1,2-dichloroethane

Super conducting

material with

nanoscopic effects

on electric transport

properties 
Table 16.2.2 (Cont.)

\begin{tabular}{|c|c|c|c|c|c|}
\hline $\begin{array}{l}\text { Metal } \\
\text { deposited }\end{array}$ & $\begin{array}{l}\text { Templating } \\
\text { membrane }\end{array}$ & Electrodeposition conditions & Nanomaterial obtained & Note & References \\
\hline $\mathrm{Co} / \mathrm{Cu}$ & Polycarbonate & $\begin{array}{l}\text { Sulfate bath: } 10^{-3} \mathrm{M} \mathrm{Cu}, 0.5 \mathrm{M} \mathrm{Co}, \\
\text { potentiostatic pulsed }(-0.2 \text { and }-0.9 \mathrm{~V})\end{array}$ & $\begin{array}{l}\mathrm{Co} / \mathrm{Cu} \text { multilayered } \\
\text { wires }\end{array}$ & $\begin{array}{l}\text { Giant } \\
\text { magnetoresistance }\end{array}$ & $(52)$ \\
\hline $\mathrm{Ni} / \mathrm{Cu}$ & Polycarbonate & $\begin{array}{l}2 \mathrm{M} \text { Nickel sulfamate, } 0.02 \mathrm{M} \text { copper sulfate, } \\
0.5 \mathrm{M} \text { boric acid, room temperature, } \mathrm{pH}= \\
3.5-4.0 \text {; potentiostatic pulsed; for } \mathrm{Cu}:-0.80 \mathrm{~V} \text {; } \\
\text { for } \mathrm{Ni}:-1.90 \mathrm{~V} \text { vs. } \mathrm{SCE}\end{array}$ & $\begin{array}{l}\text { Multilayered wires } \\
(\phi=60-80 \mathrm{~nm} \\
5 \mu \mathrm{m} \text { length })\end{array}$ & & $(51)$ \\
\hline $\mathrm{NiFe}$ & Alumina & $\begin{array}{l}6 \mathrm{~g} / \mathrm{L} \mathrm{FeSO}{ }_{4}\left(7 \mathrm{H}_{2} \mathrm{O}, 218 \mathrm{~g} / \mathrm{L} \mathrm{NiSO}_{4}\left(7 \mathrm{H}_{2} \mathrm{O}\right.\right. \\
40 \mathrm{~g} / \mathrm{L} \mathrm{H}_{3} \mathrm{BO}_{3}, \mathrm{pH}=3.6, \text { current density: } \\
0.3-0.8 \mathrm{~mA} / \mathrm{cm}^{2}, \text { two-electrode cell }\end{array}$ & Magnetic nanowires & & (57) \\
\hline
\end{tabular}


(v) Deposition is carried out for $9 \mathrm{~h}$ more to give a total of $24 \mathrm{~h}$ of electroless deposition.

(vi) The membrane is removed from the plating solution, rinsed with water, and immersed for approximately $6 \mathrm{~h}$ in $10 \% \mathrm{HNO}_{3}$ to eliminate traces of tin or silver.

(vii) The membrane is then rinsed with water and dried in air.

Note that if the plating procedure is stopped after a relatively short time, Au nanotubes are formed within the pores (70-73). To fill the pores completely and obtain nanowires, the electroless plating process must proceed for about $24 \mathrm{~h}$ as described above (5). In order to slow the kinetics of the deposition, the process is performed between 0 and $5{ }^{\circ} \mathrm{C}$.

In contrast to electrochemical template deposition, in the electroless method, the growth of the metal layer starts from the sensitized/activated sites located on the pore walls and progresses from the pore walls toward the center of the pore. This is the reason why stopping the deposition at short times results in hollow metal nanomaterials such as nanotubes (70). In fabricating Au nanotubes, it is also important to control the size of the gold particles that are deposited on the pore walls. This is achieved by controlling the $\mathrm{pH}$ of the deposition bath at a value around 10, for example, by adding carbonate buffer (73). After completion of the deposition, it is possible to separate the nanowires or nanotubes from the template membrane (see Section 16.2.3.3) or to keep them in the template. By keeping metal nanotubes in the membrane, it is possible to obtain separation membranes with metallized pores $(71,72)$ which can be further functionalized chemically by resorting to thiol chemistry (73), for example. In contrast, NEEs can be fabricated from the continuous metal nanowires which are kept inside the template membrane.

Examples of nanomaterials obtained by template electroless deposition of metals are listed in Table 16.2.3.

A new method for the chemical deposition of carbon/gold composite nanotubes in alumina templates has been proposed recently (79). It is based on the impregnation of the template pores with diluted hydrogen tetrachloroaurate $\left(\mathrm{HAuCl}_{4}\right)$ /acetone solutions and subsequent thermolysis. Gold(III) is reduced, whereas the solvent acetone is oxidized. The results are nanotubes whose walls consist of gold nanocrystals supported by amorphous carbon. The authors report that when the template pores have a diameter smaller than $180 \mathrm{~nm}$, single crystal gold nanowires are obtained.

An elegant way to obtain nanotubes made of preformed metal nanoparticles (named nanoparticle nanotubes (NPNT)) has been reported recently by Rubinstein and coworkers (80). Their method is based on the assembly of gold or silver nanoparticles on the pore walls of a silane-treated alumina template. Following a published procedure (81), the silyl groups of 3-aminopropyl trimethoxysilane react with the hydroxyl groups on the alumina surface (80), thus leaving the amine groups available for binding the metal nanoparticles. The particles self-assemble and coalesce at room temperature within the pores to form the NPNTs.

\subsubsection{Separation from the template}

When the goal of the deposition is to obtain freestanding nanostructures in the form of nanowires, nanotubes, or nanocones, then the nanomaterial must be separated from the templating membrane. Track-etched membranes can be dissolved by using suitable organic solvents such as $\mathrm{CH}_{2} \mathrm{Cl}_{2}$ for PC $(3,47)$ or 1,1,1,3,3,3-hexafluoro-2-propanol (HFIP) for 


\section{Table 16.2.3}

Examples of conditions and materials used for the electroless template deposition of metals

\begin{tabular}{|c|c|c|c|c|}
\hline $\begin{array}{l}\text { Metal } \\
\text { deposited }\end{array}$ & $\begin{array}{l}\text { Templating } \\
\text { membrane }\end{array}$ & Electroless conditions & Nanomaterial obtained & References \\
\hline $\mathrm{Au}$ & Polycarbonate & $\begin{array}{l}\text { Sensitization: } 0.026 \mathrm{M} \mathrm{SnCl}_{2}+0.07 \mathrm{M} \text { trifluoroacetic acid, } \\
50 / 50 \text { methanol/water; activation: } 0.029 \mathrm{M} \mathrm{AgNO}_{3} \text {; } \mathrm{Au} \text { deposition: } \\
\left.7.79 \times 10^{-3} \mathrm{M} \mathrm{Na} \mathrm{Au}_{3} \mathrm{AO} \mathrm{SO}_{3}\right)_{2}+0.127 \mathrm{M} \mathrm{Na}_{2} \mathrm{SO}_{3}+0.625 \mathrm{M} \\
\text { formaldehyde; temperature } \sim 0{ }^{\circ} \mathrm{C}\end{array}$ & Wires & (5) \\
\hline $\mathrm{Au}$ & Polycarbonate & $\begin{array}{l}\text { The same as reference (5), but with a different deposition time } \\
\text { and at } \mathrm{pH}=10 \text { controlled with } 0.025 \mathrm{M} \mathrm{NaHCO} / \mathrm{H}_{2} \mathrm{SO}_{4}\end{array}$ & Nanotubes & $(73)$ \\
\hline $\mathrm{Au}$ & $\begin{array}{l}\text { Home-etched } \\
\text { polycarbonate (37) } \\
\text { or poly(ethylene } \\
\text { terephthalate) (40) } \\
\text { with conical pores }\end{array}$ & Same as above and in reference (73) & Nanocones & $(37,40)$ \\
\hline $\mathrm{Ag}$ & Polycarbonate & $\begin{array}{l}\text { 1st step: } 0.026 \mathrm{M} \mathrm{SnCl}_{2}+0.07 \mathrm{M} \text { trifluoroacetic acid; } 2 \text { nd step: } \\
2.3 \mathrm{~g} \mathrm{AgNO}_{3}+1.9 \mathrm{~mL} \mathrm{NH}_{4} \mathrm{OH}+22.7 \mathrm{~mL} \mathrm{H}_{2} \mathrm{O} ; 3 \mathrm{rd} \text { step: } \\
7.95 \mathrm{~g} \mathrm{KNaC}_{4} \mathrm{O}_{6} \mathrm{H}_{4}+0.57 \mathrm{~g} \mathrm{MgSO}_{4}+18.2 \mathrm{~mL} \mathrm{H}_{2} \mathrm{O} \text {, } \\
\text { temperature }=35{ }^{\circ} \mathrm{C}\end{array}$ & Nanotubes & (74) \\
\hline $\mathrm{Cu}$ & Polycarbonate & $\begin{array}{l}\text { Pre-activation: } \mathrm{SnCl}_{2} 10 \mathrm{~g} / \mathrm{L}+10 \mathrm{~mL} / \mathrm{L} \mathrm{HCl} \text {; activation: } \\
\mathrm{PdCl}_{2} 0.1 \mathrm{~g} / \mathrm{L}+10 \mathrm{~mL} \mathrm{HCl} \text {; deposition: } \mathrm{CuSO}_{4} 5 \mathrm{H}_{2} \mathrm{O} 10 \mathrm{~g} / \mathrm{L}+ \\
\mathrm{NaOH} 12 \mathrm{~g} / \mathrm{L}(\mathrm{pH}=12.1)+\text { tartaric acid } 18 \mathrm{~g} / \mathrm{L}(\text { complexing } \\
\text { agent })+ \text { formaldehyde } 10 \mathrm{~mL} / \mathrm{L} \text { (reducing agent) }\end{array}$ & $\begin{array}{l}\text { Tubes: cylindrical, } \\
\text { cigar-shaped, conical; } \\
\phi_{\text {external }}=300-2000 \mathrm{~nm} \text {; } \\
\phi_{\text {internal }}=\text { function of } \\
\text { deposition time }\end{array}$ & $(75)$ \\
\hline $\mathrm{Pd}$ & $\begin{array}{l}\text { Polycarbonate, } \\
\text { alumina }\end{array}$ & $\begin{array}{l}\text { Ammonium tetrachloropalladate }+ \text { decamethylferrocene in } \\
\text { 1,2-dichloroethane }\end{array}$ & Nanoparticles & $(76)$ \\
\hline $\mathrm{Ni}-\mathrm{P}$ & Polycarbonate & $\begin{array}{l}\text { Sensitization: } 0.026 \mathrm{M} \mathrm{SnCl}{ }_{2}+0.07 \mathrm{M} \text { trifluoroacetic acid, } \\
\text { methanol/water solution; activation: } 0.25 \mathrm{~g} / \mathrm{L} \mathrm{PdCl}_{2}+1.0 \mathrm{~g} / \mathrm{L} \\
\mathrm{HCl} ; \mathrm{Ni} \text { plating: } \mathrm{NaH}_{2} \mathrm{PO}_{2} \cdot \mathrm{H}_{2} \mathrm{O} 20 \mathrm{~g} / \mathrm{L}, \mathrm{NiSO}_{4} \cdot 6 \mathrm{H}_{2} \mathrm{O} 40 \mathrm{~g} / \mathrm{L} \\
\mathrm{NaC}_{6} \mathrm{H}_{5} \mathrm{O}_{7} \cdot 2 \mathrm{H}_{2} \mathrm{O} 100 \mathrm{~g} / \mathrm{L}, \mathrm{NH}_{4} \mathrm{Cl} 50 \mathrm{~g} / \mathrm{L} ; \mathrm{NH}_{4} \mathrm{OH} \text { (pH adjustment) }\end{array}$ & $\begin{array}{l}\text { Ni-P tubules electrode array; } \\
\text { internal diameter } \cong 180 \mathrm{~nm} \\
\text { wall thickness } \cong 20 \mathrm{~nm} \text {; } \\
\text { length } 2 \mu \mathrm{m}\end{array}$ & $(77)$ \\
\hline $\mathrm{Co}-\mathrm{Fe}-\mathrm{P}$ & Alumina & $\begin{array}{l}\text { Sensitization: } \mathrm{SnCl}_{2} 10 \mathrm{~g} / \mathrm{L} \text {; activation: } \mathrm{PdCl}_{2} 1 \mathrm{~g} / \mathrm{L} \text {; plating: } \\
\mathrm{CoSO}_{4} \cdot 7 \mathrm{H}_{2} \mathrm{O} 20 \mathrm{~g} / \mathrm{L}+\mathrm{FeSO}_{4} \cdot 7 \mathrm{H}_{2} \mathrm{O} 5 \mathrm{~g} / \mathrm{L}+\mathrm{NaH}_{2} \mathrm{PO}_{2} \cdot \mathrm{H}_{2} \mathrm{O} \\
25 \mathrm{~g} / \mathrm{L}+\mathrm{KNa}\left(\mathrm{C}_{4} \mathrm{H}_{4} \mathrm{O}_{6}\right) \cdot 4 \mathrm{H}_{2} \mathrm{O} \text { (Rochelle salt) } 60 \mathrm{~g} / \mathrm{L} \text { at } 80-85^{\circ} \mathrm{C}\end{array}$ & Nanowire arrays & $(78)$ \\
\hline
\end{tabular}


PET (40). Polymers can also be etched by treatment with oxygen plasma (82). Dissolution of alumina templates is easily achieved by immersion in strong alkali such as $5 \mathrm{M} \mathrm{KOH}$ or $\mathrm{NaOH}(20)$.

\subsubsection{Morphological and optical properties}

\subsubsection{SEM-TEM studies}

Scanning or transmission electron microscopy (SEM or TEM, respectively) are typically used for performing morphological characterization of nanomaterials obtained by template synthesis. The resolution of the images is improved if the nanomaterial is separated from the host membrane.

As an example, Figure 16.2.6 shows SEM and TEM images of nanostrucutures produced in PC templates. Figure 16.2.6A images $30 \mathrm{~nm}$ nanofibers of an NEE still in the
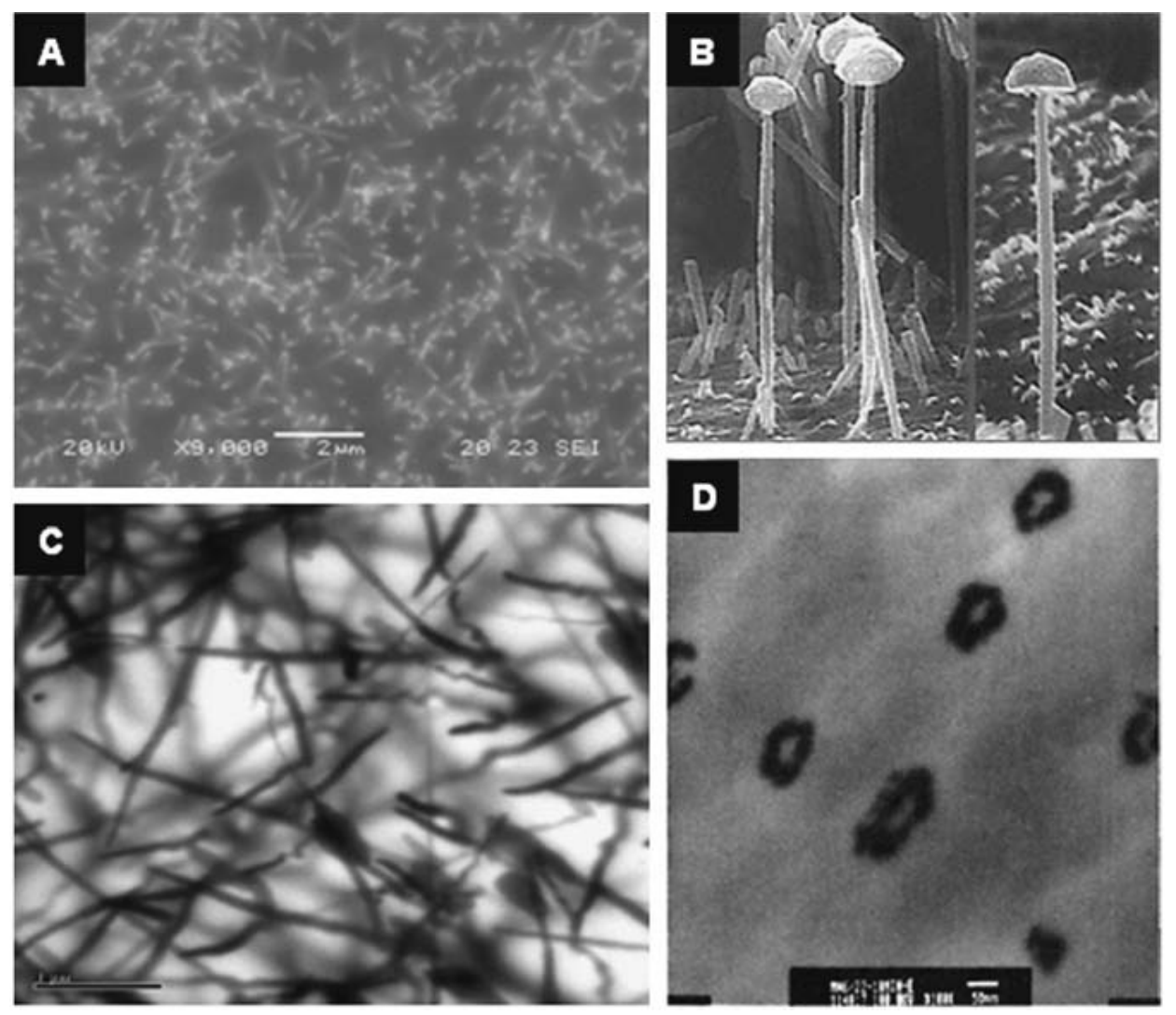

Figure 16.2.6 (A) SEM image of the surface of an Au-NEE, in PC template, pore diameter $30 \mathrm{~nm}$; (B) SEM image of Ni wires, template pore diameter $80 \mathrm{~nm}$, after dissolution of the PC membrane; (C) TEM image of an Au-NEE, template pore diameter $30 \mathrm{~nm}$ with the nanofibers still embedded in the polycarbonate; (D) TEM image of a microtomed section of a PC membrane after deposition of $\mathrm{Au}$ tubes within the pores of the membrane. Reprinted with permission from reference (83) for (A) and (C), reference (47) for (B), and reference (5) for (D). 
polymer membrane. The surface gold layers present on both sides of the membrane at the end of the deposition step have been removed before the SEM analysis. This image clearly shows the surface of the nanodisks emerging from the PC template. The fading lines behind the nanodisks are the traces of the nanofibers that grew inside the membrane. The observation of such traces is related to the partial transparency of the PC template to the electron beam. The nanofibers are not aligned parallel, but have a considerable angular distribution as a consequence of the angles of the original trajectories of the tracks used to sensitize the membrane before etching of the pores in the membrane production (47). Figure 16.2.6B shows that more detailed images are obtained after the removal of the guest membrane by dissolution with $\mathrm{CH}_{2} \mathrm{Cl}_{2}$; in this case, the nickel nanowires have a curious mushroom shape (47). Figure 16.2.6C shows that information about the inner structure of the nanofibers inside PC templates can be obtained by TEM without removal of the guest membrane thanks to the transparency of the PC to electron beams (83). However, some distortion and artifacts cause apparent whirling and bending of the fibers and are attributed to possible interactions between the e-beam and the polymer. High-resolution TEM images of nanowires isolated from template membranes $(51,63)$ also permit the study of the structure and crystallinity of the nanofibers. Finally, Figure 16.2.6.D demonstrates that microtomy can also be used to characterize templated nanostrucutures, in this case, gold nanotubes of $30 \mathrm{~nm}$ diameter in PC (5).

\subsubsection{Optical properties}

Nanometals have interesting optical properties, whether they are inside the host template or liberated from it. For example, suspensions of nanoscopic Au particles can be pink, purple, or blue, depending on the diameter of the particles. These colors arise from the plasmon resonance absorption of the nanometal particle (25). Membranes containing $\mathrm{Au}$ nanowires also show this plasmon resonance band, and as a result, such membranes can show a wide variety of colors (42). This absorption in the visible region, typically between 400 and $800 \mathrm{~nm}$ for 10-30 nm diameter particles, provides an interesting optical approach to characterizing Au nanowires (5).

One attractive feature of host templates such as porous anodic alumina is the parallel alignment of the pores. This feature permits the straightforward interpretation of the plasmon resonance spectra of non-spherical metal particles that are prepared within such pores. Figure 16.2.7A shows the plasmon resonance spectra of a series of gold nanorod/ porous alumina composite films measured with light incident normal to the film surface $(23,84)$.

Since the rods are also aligned perpendicular to the film surfaces, the electric field of the light is incident only along the diameter (or short axis) of the rods. Thus, only one plasmon resonance band appears in each spectrum (the transverse resonance). An increase in the aspect ratio (length/diameter) of the particles causes a blue shift in the maximum of the plasmon resonance absorption (17). The change in the incidence angle $(\theta)$ modifies the spectrum (see Figure 16.2.7B): as $\theta$ increases, a second spectral band grows in corresponding to the long-axis resonance. Converse to the transverse resonance case, the wavelength maximum of the longitudinal resonance increases with increasing particle aspect ratio $(23,85)$. 

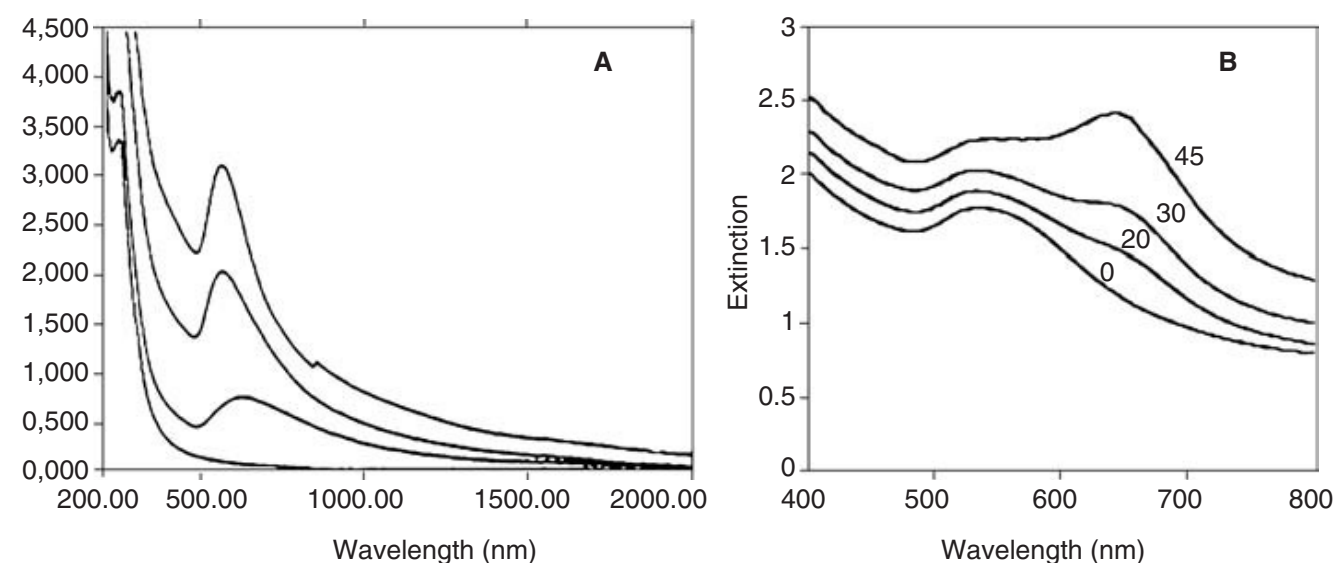

Figure 16.2.7 UV-vis spectra of oriented Au nanoparticle composites. (A) Normal incidence spectra of $60 \mathrm{~nm}$ diameter Au rods in alumina membrane; particle aspect ratios: (1) blank; (2) 1; (3) 3.38 ; (4) 5.28. (B) Polarization spectra of Au nanorods (diameter $=30 \pm 4 \mathrm{~nm}$; length $=54 \pm$ $4 \mathrm{~nm}$ ) in host alumina membrane at different incident angles $\theta$, indicated in the graph and measured in degrees relative to membrane normal surface. Adapted with permission from references $(23,84)$.

The spectra resulting from the aqueous dispersion of the nanorods removed from the host template show two plasmon resonance bands: a strong one at long wavelengths due to the long-axis resonance and a weaker one at shorter wavelengths that originates from the transverse resonance (85).

All of these optical features are useful in characterizing the shape and spatial distribution of the nanostructures.

\subsubsection{Electrochemistry with template nanomaterials: nanoelectrode ensembles}

Nanoelectrode ensembles (NEEs) (see also Chapter 10 of this handbook) are nanotechbased electroanalytical tools which find application in a variety of fields ranging from electroanalysis to sensors (86) and electronics (7). They are fabricated by growing metal nanowires in the pores of a template, typically a PC nanoporous membrane. The density of the pores in the template determines the number of Au-disk nanoelectrode elements per $\mathrm{cm}^{2}$ of NEE surface and, correspondingly, the average distance between the nanoelectrode elements. Such electrode systems proved to be valuable tools for trace determinations and kinetics studies by simply using cyclic voltammetry (CV) $(5,69,86,97)$.

The NEE fabrication procedure used in our laboratory is described below and is based on that reported in reference (5) apart from minor modifications such as positioning of the copper tape (see below and reference (83)). A scheme of an NEE is presented in Figure 16.2.8; specific details on the construction can be found in the original papers $(5,83)$ as well as in recent reviews $(7,86,87)$. The starting material is a piece of golden PC membrane with 




a

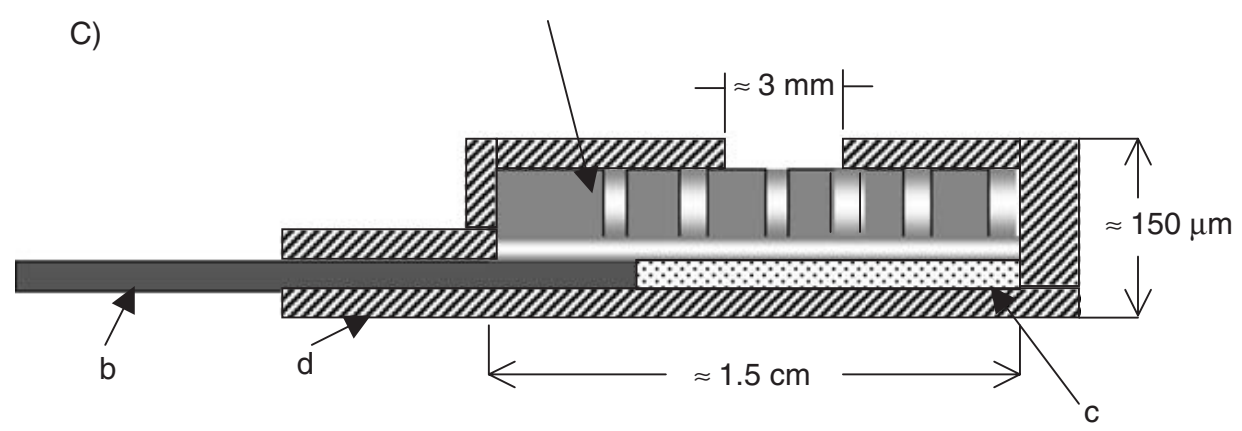

Figure 16.2.8 Scheme of an Au-NEE prepared using a track-etched polycarbonate membrane as template (A). Particular of the section of the active area; (B) top view; (C) section of the all NEE ready for use as working electrode. (a) Track-etched golden membrane; (b) copper adhesive tape with conductive glue to connect to instrumentation; (c) aluminum adhesive foil with non-conductive glue; (d) insulating tape. Note: Some dimensions are only indicative and not in scale.

gold within the pores and on both faces of the membrane; this membrane, named $\mathrm{Au} / \mathrm{Au}-$ $\mathrm{PC} / \mathrm{Au}$, is the final product of the Au electroless deposition process. In particular, a $5 \times 6 \mathrm{~mm}$ piece of the Au/Au-PC/Au membrane is first affixed to a $6 \times 15 \mathrm{~mm}$ piece of adhesive aluminum foil tape. The $\mathrm{Au} / \mathrm{Au}-\mathrm{PC} / \mathrm{Au}$ membrane is placed on the $\mathrm{Al}$ foil tape such that the Au film covering the rough face of the membrane is down (i.e., against the adhesive). A rectangular strip $(6 \times 40 \mathrm{~mm})$ of copper foil with a conductive adhesive is affixed to the lower $\mathrm{Au}$-coated surface of the $\mathrm{Au} / \mathrm{Au}-\mathrm{PC} / \mathrm{Au}$ membrane between the $\mathrm{Au}$ on the rough face 
of the membrane and the $\mathrm{Al}$ foil. The copper foil is positioned such that it covers only about $1 \mathrm{~mm}$ of the $6 \mathrm{~mm}$ length of the Au/Au-PC/Au membrane. This copper foil tape acts as a current collector and working electrode lead for the NEE. The upper Au surface layer from the portion of the $\mathrm{Au} / \mathrm{Au}-\mathrm{PC} / \mathrm{Au}$ membrane not covered by the $\mathrm{Cu}$ foil tape is then removed by simply applying and then removing a strip of Scotch tape. Removal of the $\mathrm{Au}$ surface layer exposes the disk-shaped ends of the Au wires within the pores of the membrane. These nanodisks will become the active electrode elements. At this point, the NEE assembly is heat-treated at $150{ }^{\circ} \mathrm{C}$ for $15 \mathrm{~min}$. This procedure produces a water-tight seal between the Au nanowires and the pore walls. Finally, strips of strapping tape are applied to the lower and upper surfaces of the assembly to insulate the $\mathrm{Al}$ and $\mathrm{Cu}$ foil tapes. A hole (diameter of $3 \mathrm{~mm}$ ) is punched into the upper piece of tape prior to the placement on the assembly. This hole defines the geometric area $\left(A_{\text {geom }}\right)$ of the NEE. All the nanoelectrodes in the NEE are connected to each other, so that they all experience the same applied potential.

Track-etched polymer membranes are preferred for NEE fabrication over alumina membranes because track-etched membranes are not brittle and they have smaller pore densities. From an electroanalytical viewpoint, the latter is an important feature since it reduces the interactions between individual nanoelectrode elements (see below).

\subsubsection{Current signals of nanoelectrode ensembles}

From a voltammetric viewpoint, an NEE is a large assembly of very small ultramicrolectrodes confined in a rather small space. As shown in Figure 16.2.9, NEEs can exhibit three distinct voltammetric response regimes depending on the scan rate or distance between the nanoelectrode elements $(88,89$; see also Chapter 10 of this handbook)-(A) Total Overlap Regime: when radial diffusion boundary layers overlap totally (slow scan rates and/or small distance between nanoelectrodes); (B) Pure Radial: when the nanoelectrodes behave independently (higher scan rates, larger distances between nanoelectrodes; (C) Linear: when the nanoelectrodes behave as isolated planar electrodes (very high scan rates).

The transition from the Total Overlap to the Pure Radial Regime has been demonstrated experimentally as a function of the template pore density (88). For electroanalytical applications, the most advantageous regimes are the Total Overlap and the Pure Radial Regimes because they give high faradaic-to-capacitive current ratios (90). The diffusion regime usually observed at NEEs fabricated from commercial track-etched membranes is the Total Overlap Regime (5).

Relevant geometric parameters that define the behavior of NEEs include:

(i) Total geometric area $\left(\boldsymbol{A}_{\text {geom }}\right)$ : Overall area (nanodisks plus bare membrane area) of the ensemble exposed to the sample solution; typical values for this parameter range from 0.008 to $0.580 \mathrm{~cm}^{2}$ (91). $A_{\text {geom }}$ is determined by the dimension of the hole punched into the insulator (see Figure 16.2.8).

(ii) Active area $\left(\boldsymbol{A}_{\mathrm{act}}\right)$ : Area of the metal nanoelectrode elements alone. It can be calculated by the pore density $(p)$, the average radius of the pores $(r)$, and the geometric area, according to the following equation:

$$
A_{\text {act }}=\pi r^{2} p A_{\text {geom }}
$$


A)

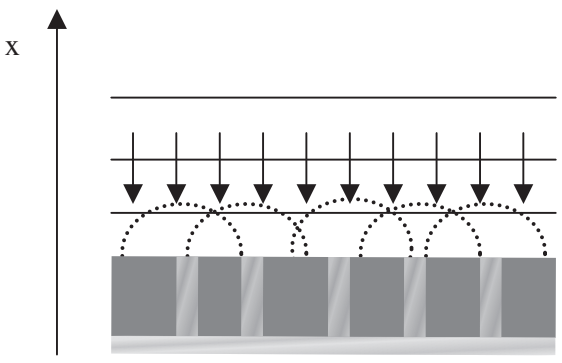

B)

$\mathrm{x}$

$$
\uparrow
$$



C)
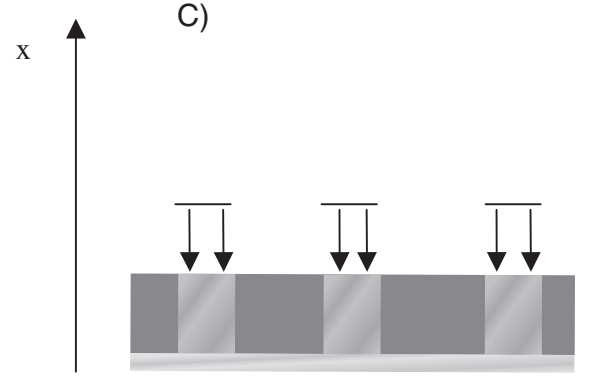

\section{$I_{p}=2.69 \times 10^{5} n^{3 / 2} A_{g e o m} v^{1 / 2} D^{1 / 2} C$}

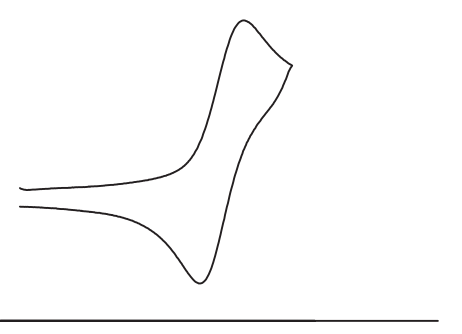

$\mathrm{E}$



E

$I_{p}=2.69 \times 10^{5} n^{3 / 2} A_{\text {act }} v^{1 / 2} D^{1 / 2} C$

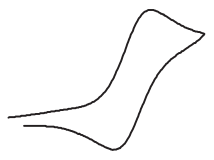

E

Figure 16.2.9 Schematic drawing of the different diffusional regimes at NEE: (A) Total Overlap; (B) Pure Radial; (C) Linear active. The scan rate or the distance between the nanodisk elements increases from (A) to (C). Relevant equations for peak currents (A and C) and plateau current (B) refer to reversible redox systems. $A_{\text {act }}$ is the active area (nanodisk surface), $A_{\text {geom }}$ is the total geometric area of the ensemble (nanodisks and insulator), $q$ is the nanodisk density (disk $\mathrm{cm}^{-2}$ ), and all other symbols have their usual meaning. Reprinted with permission from reference (86). (for colour version: see colour section at the end of the book).

(iii) Fractional electrode area $(\boldsymbol{f})$ : It is defined as the ratio between active and geometric areas:

$$
f=\frac{A_{\mathrm{act}}}{A_{\mathrm{geom}}}
$$

By substitution of equation (16.2.1), it can be easily calculated also as:

$$
f=\pi r^{2} p
$$


The faradaic peak current at an NEE operating in the Total Overlap Regime for a reversible redox system obeys the Randles-Sevcik equation (5):

$$
i_{\mathrm{p}}=2.69 \times 10^{5} n^{3 / 2} A_{\text {geom }} D^{1 / 2} C^{*} v^{1 / 2}
$$

where $i_{\mathrm{p}}$ is the peak current (A), $A_{\text {geom }}$ is the geometric area of the ensemble $\left(\mathrm{cm}^{2}\right), D$ is the diffusion coefficient $\left(\mathrm{cm}^{2} \mathrm{sec}^{-1}\right), C^{*}$ is the redox species bulk concentration $\left(\mathrm{mol} \mathrm{cm}^{-3}\right)$, and $v$ is the scan rate $\left(\mathrm{V} \mathrm{sec}^{-1}\right)$.

At the same NEE, the double-layer charging current $\left(i_{\mathrm{C}}\right)$ is proportional to the area of the electrode elements (active area, $\left.A_{\text {act }}\right)(92,93)$ :

$$
i_{\mathrm{C}}=v C_{\mathrm{dl}} A_{\mathrm{act}}
$$

where $C_{\mathrm{dl}}$ is the double-layer capacitance of the metal nanodisks of the NEE. Typical $i_{\mathrm{C}}$ values will be in the range of 1 and $2 \mathrm{nA}$ (based on a $C_{\mathrm{dl}}$ value between 20 and $40 \mu \mathrm{F} \mathrm{cm}^{-2}$ (93), a gold NEE with $A_{\text {geom }}=0.079 \mathrm{~cm}^{2}$, pore density $=6 \times 10^{8}$ pore $\mathrm{cm}^{-2}$, average pore radius $=1.5 \times 10^{-6} \mathrm{~cm}$, and scan rate $\left.(v)=0.1 \mathrm{~V} \mathrm{sec}^{-1}\right)$.

Faradaic-to-capacitive current ratios at an NEE and a conventional electrode with the same geometric area are related by equation (16.2.6) (86):

$$
\left(\frac{i_{\mathrm{F}}}{i_{\mathrm{C}}}\right)_{\mathrm{NEE}}=\left(\frac{i_{\mathrm{F}}}{i_{\mathrm{C}}}\right)_{\text {conv }}\left(\frac{A_{\mathrm{geom}}}{A_{\mathrm{act}}}\right)=\left(\frac{i_{\mathrm{F}}}{i_{\mathrm{C}}}\right)_{\mathrm{conv}}\left(\frac{1}{f}\right)
$$

This ratio is larger at the NEE than that at the conventional electrode by a factor that is the reciprocal of the fractional electrode area $f$. Since typical $f$ values for NEEs are between $10^{-3}$ and $10^{-2}, i_{\mathrm{F}} / i_{\mathrm{C}}$ ratios at NEEs can be $2-3$ orders of magnitude higher than the ratios at conventional electrodes of the same geometric area. Thus, detection limits at NEEs are 2-3 orders of magnitude lower than that at regular electrodes $(5,68,69)$.

From a practical viewpoint, the values given for the faradaic peak currents and for the double-layer charging currents calculated by equations (16.2.4) and (16.2.5) can be used to discriminate between "good" and "bad" NEEs. In our laboratory, from a commercial PC nanoporous membrane of $47 \mathrm{~mm}$ diameter, we prepare a rather large number (typically around 30) of NEEs, which are then selected on the basis of the agreement between theoretical and experimental $i_{\mathrm{F}}$ and $i_{\mathrm{C}}$ values. The latter can be obtained from the cyclic voltammogram recorded in supporting electrolyte alone $(5 ; 92$, p. 18) and the former by recording the $\mathrm{CV}$ in solution containing a known concentration of a reversible redox probe of known diffusion coefficient. From the CVs with and without the redox probe we select as "good NEEs" those that are characterized by $i_{\mathrm{F}(\exp )}=i_{\mathrm{F}(\text { theor })}(1 \pm 0.2)$ and $i_{\mathrm{C}(\exp )}=i_{\mathrm{C}(\text { theor })}(1 \pm 0.5)$, where $i_{\mathrm{F(exp)}}$ and $i_{\mathrm{C}(\exp )}$ are the faradaic and double-layer charging currents measured experimentally, and $i_{\mathrm{F}(\text { theor })}$ and $i_{\mathrm{C}(\text { theor })}$ are values calculated by equations (16.2.4) and (16.2.5). Figure 16.2.10 reports typical experimental CVs (dotted and dashed lines) recorded at "good" (part A) and "bad" NEEs (part B). The comparison with the simulated $\mathrm{CV}$ curves (full lines in the same figure) allows one to immediately distinguish good ensembles from bad ones. Note that the two experimental curves in part B show the features typical for two kinds of defects which can be produced during the NEEs preparation. 

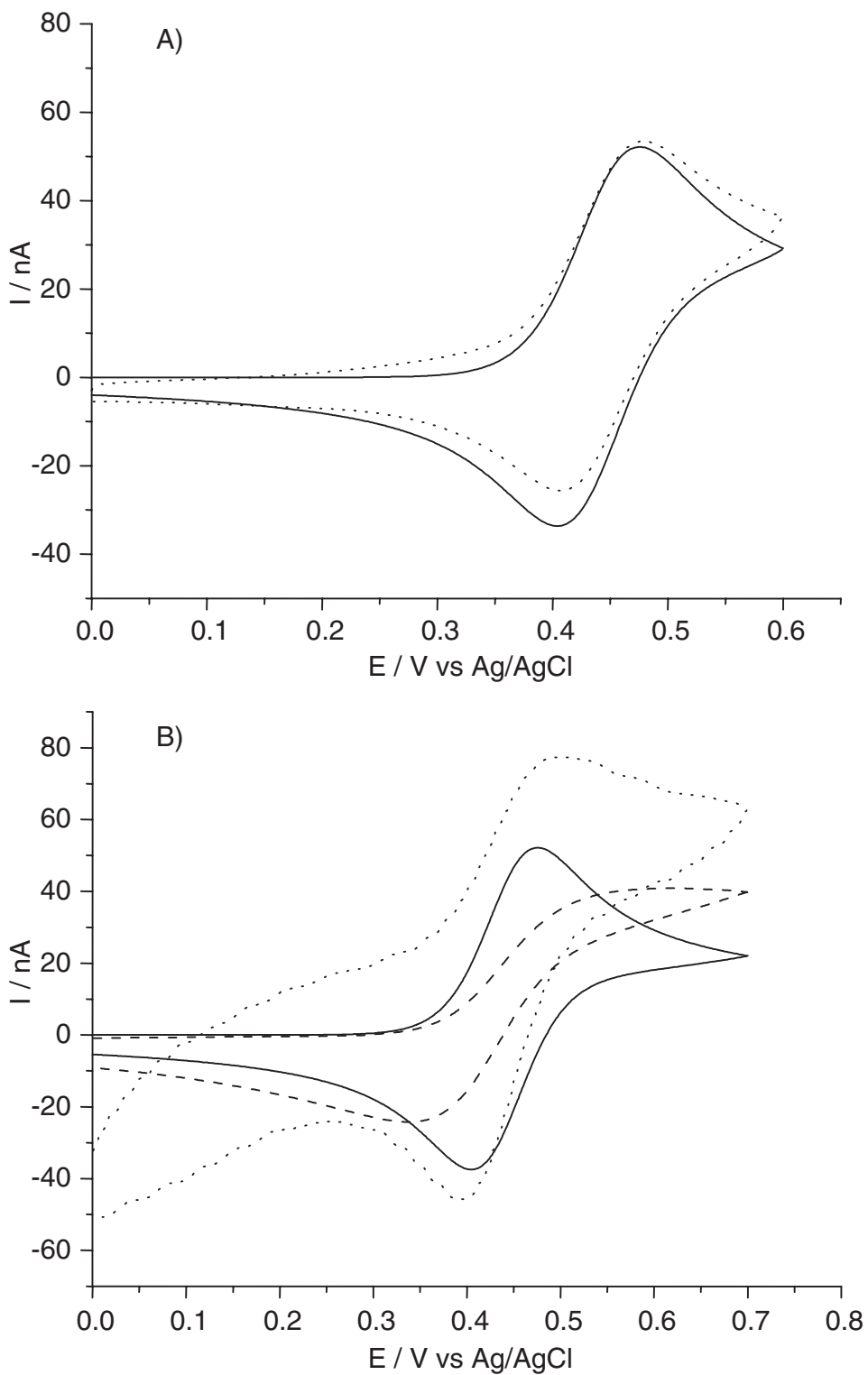

Figure 16.2.10 Comparison between digital simulations (-) and experimental CVs; the experimental curves refer to (A) ( $\cdots$ ) a "good" NEE; (B) ( $\cdots$ and - - -) a "bad" NEE. Experimental conditions: $10^{-2} \mathrm{M} \mathrm{NaNO}_{3}, 6 \times 10^{-6} \mathrm{M}$ (ferrocenylmethyl)-trimethylammonium hexafluorophosphate, $A_{\text {geom }}=0.07 \mathrm{~cm}^{2}$, scan rate $50 \mathrm{mV} \mathrm{sec}^{-1}$. Additional parameters used for the digital simulation (run with $\mathrm{CH}$ Instruments software): $E^{\circ}=0.44 \mathrm{~V}, k^{\circ}=0.007$ (which is really $k_{\text {app }}^{\circ}$, see equation (16.2.8)), and $D=4 \times 10^{-6} \mathrm{~cm}^{2} \mathrm{sec}^{-1}$ (94).

The dotted-line voltammogram indicates that this NEE is affected by a large capacitive current, which was probably produced by poor sealing between the nanowires and the surrounding PC insulator and/or by heavy scratches or abrasions of the PC membrane caused by improper handling of the NEE. The dashed-line voltammogram shows a radial diffusive contribution to the overall signal and a current smaller than the theoretical one. This 
suggests larger distances between and a smaller number of nanoelectrode elements with respect to expected values, possibly due to not all of the pores being filled by gold in the final NEE. The number of NEEs that satisfy the above criteria ranges typically from 25 to $40 \%$ in a batch of NEEs obtained from one PC membrane.

\subsubsection{Electron transfer kinetics}

A distinctive feature of NEEs is that electron transfer kinetics appear slower than those at conventional electrodes (5). In fact, NEEs behave as electrodes with a partially blocked surface (PBE). According to the model elaborated by Amatore et al. (95), the current response at a PBE is identical to that at a bare electrode of the same overall geometric area but with a smaller apparent standard rate constant for the electron transfer which decreases as the coverage with the blocking agent increases. Such an apparent rate constant $\left(k_{\text {app }}^{\circ}\right)$ is related to the true standard charge transfer rate constant $\left(k^{\circ}\right)$ and the fraction of blocked surface $(\vartheta)$ by the following relationship (95):

$$
k_{\text {app }}^{\circ}=k^{\circ}(1-\vartheta)
$$

Considering that $\vartheta=\left(A_{\text {geo }}-A_{\text {active }}\right) / A_{\text {geo }}$, then equation (16.2.7) can be easily converted into:

$$
k_{\text {app }}^{\circ}=k^{\circ} f
$$

where $f$ is the fractional electrode area, defined by equation (16.2.2).

In $\mathrm{CV}$ at a conventional electrode, the reversibility depends on both $k^{\circ}$ and the scan rate, while at an NEE, it depends on $k_{\text {app }}^{\circ}$ and the scan rate (5). At a conventional electrode, a redox system gives a reversible voltammetric pattern when $v^{1 / 2} \leq\left(k^{\circ} / 0.3\right)$ (see p. 239 in reference (92)). At NEEs, equation (16.2.8) suggests that, for a certain redox couple, the scan rate that defines the transition between reversible and quasi-reversible behavior will be placed at a lower value than that at conventional electrodes. Note that such a boundary scan rate will decrease with decreasing $f$.

From a mechanistic viewpoint, this behavior means that with NEEs characterized by small $f$ values (for example, very small diameter nanodisks and/or very small pore densities), it is experimentally easier to measure large $k^{\circ}$ values $(5,69,94)$. Values of $k_{\text {app }}^{\circ}$ are measured typically by $\mathrm{CV}$ operating within a scan rate range where the redox system behaves quasi-reversibly $(92,93)$. By the analysis of the $\Delta E_{\mathrm{p}}$ dependence on the scan rate (93) and by using suitable working curves (96), $k^{0}$ values are readily obtained. At NEEs, quasi-reversible behavior is observed at scan rates $2-3$ orders of magnitude lower than those at conventional electrodes (depending on $f$ ). What is measured experimentally under such conditions is really the smaller $k_{\text {app }}^{\circ}$ value, which is converted into the larger $k^{\circ}$ by equation $(16.2 .8)(69,94)$.

\subsubsection{Electroanalysis with NEEs}

The potential window accessible at gold disk NEEs (Au-NEEs) has been studied in detail $(5,69)$. It was shown that the limit at negative potentials is determined by the hydrogen evolution reaction and depends on the solution $\mathrm{pH}(69)$. The limit at positive potentials is 
given by the formation of gold oxide. NEEs are typically used at low analyte concentrations (typically from $10^{-5}$ to lower than $\left.10^{-9} \mathrm{M}\right)(5,69)$ so that faradaic peak current signals can be on the order of a few nA down to a few pA. Therefore, relatively high electronic amplification of the current signal is required. By operating with suitable amplification levels at $\mathrm{pH}$ around 7 and micromolar (or lower) analyte concentrations, the potential window accessible at $\mathrm{Au}-\mathrm{NEEs}$ is limited approximately to the range between -0.750 and $+0.800 \mathrm{~V}$ vs. $\mathrm{Ag} / \mathrm{AgCl}$. Such limits can change with the nature of the metal of which the nanoelectrode is made, but no precise information is available up to now for materials different from gold.

The ability of NEEs to furnish well-resolved cyclic voltammograms has allowed researchers to develop sensitive methods for trace determination of redox species characterized by relatively fast electron transfer kinetics and an electroactivity range within the abovementioned potential window. As explained in Section 16.2.5.2, the high sensitivity of NEEs to electron transfer kinetics causes the observation of a perfectly reversible electrochemical behavior only to very fast redox couples, while for "sluggish" redox couples, quite flattened voltammetric patterns are recorded. In addition to the application for trace electroanalysis at well-known reversible redox probes such as ferrocene derivatives or ruthenium complexes $(5,97)$, Figure 16.2.11 shows that NEEs can be used for CV at micromolar concentration levels of more complex redox systems such as organic mediators like phenothiazines (azure B in Figure 16.2.11B), methylviologen (69) (not shown), or the heme-protein cytochrome $c$ (see Figure 16.2.11A). Note that for these redox systems, $k^{\circ}$ values are $8 \times 10^{-3} \mathrm{~cm} \mathrm{sec}^{-1}$ for azure B (69) and $>0.1 \mathrm{~cm} \mathrm{sec}^{-1}$ for cytochrome $c$ (98).

The cytochrome $c$ case is noteworthy because at NEEs, well-resolved CVs are obtained in diluted solutions of the protein both with and without promoters such as 4,4'-bipyridyl typically used for promoting cytochrome $c$ electrochemistry (99-101). These promoters are generally required to avoid adsorption/denaturation $(83,102,103)$ of cytochrome $c$ on the Au surface. However, such an adsorption is concentration dependent so that lowering the cytochrome $c$ solution concentration below the adsorption limit (possible at NEEs thanks to their lower detection limit) can overcome adsorption-related problems. A similar situation has been reported for the adsorption of some organic dyes such as the phenothiazines (69).

Recently, it was shown that by etching only a layer of the templating membrane, it is possible to fabricate ensembles of 3D nanowires instead of 2D nanodisks $(82,104)$. The partial etching can be performed by either oxygen plasma (82) or partial dissolution of the PC using a mixture of ethanol and dichloromethane (105). The use of nanowire ensembles together with suitable redox indicators $(104,106,107)$ has been demonstrated to be useful for improving the sensitivity for the electrochemical detection of DNA duplexes. This example illustrates how NEEs can be used advantageously for advanced bio-electroanalytical sensing.

\subsubsection{Conclusions and prospects}

The use of nanoporous membranes as templates constitutes an attractive and practical methodology for the fabrication of nanomaterials characterized by high aspect ratios, ranging from relatively simple nanomaterials made of just one component, such as metal nanowires 




Figure 16.2.11 CVs recorded at Au-NEEs in: (A) $5 \times 10^{-6} \mathrm{M}$ cytochrome $c$ and (B) $5 \times 10^{-6} \mathrm{M}$ azure B; scan rates as indicated in the figure; supporting electrolyte in both cases: $10^{-2} \mathrm{M}$ phosphate buffer at $\mathrm{pH}=7.4$; nominal diameter of the $\mathrm{Au}$ nanodisks $=30 \mathrm{~nm}$; disks' density $=6 \times 10^{8}$ disks $\mathrm{cm}^{-2}$. Reprinted with permission from reference (83) for (A) and reference (69) for (B). 
and nanotubes, to more complex structures such as nanotubes of nanoparticles, nanotubes in nanotubes, or segmented nanowires.

The description presented here focused mainly on metal-based nanomaterials. However, the same principles can find application and extension to the preparation of nanostructures made of organic polymers, oxides, and salts.

It is reasonable to think that such a membrane-based approach to the synthesis of nanomaterials will find wider application due to the fact that it allows easy fabrication and rapid screening of the properties of new and unusual nanomaterials.

Template synthesis has made accessible to almost any electrochemical laboratory the fabrication of electrode systems with critical dimensions in the nanometer domain. Future research efforts will likely be devoted to fundamental studies aimed at better understanding the effects related to decreasing the size of electrodes to dimensions comparable or smaller than the dimensions of the double- and diffusion layers. From a practical and application perspective, the next frontier will focus on the development of methods and materials that allow one to better control the size, spatial distribution, and addressability of the single nanoelectrode elements in rather complex arrays or ensembles.

\section{REFERENCES}

1. G. E. Possin, Rev. Sci. Instrum. 41, 772 (1970).

2. W. D. Williams, N. Giordano, Rev. Sci. Instrum. 55, 410 (1984).

3. R. M. Penner, C. R. Martin, Anal. Chem. 59, 2625 (1987).

4. J. F. Cheng, C. R. Martin, Anal. Chem. 60, 2163 (1988).

5. V. P. Menon, C. R. Martin, Anal. Chem. 67, 1920 (1995).

6. K. Uosaki, K. Okazaki, H. Kita, H. Takahashi, Anal. Chem. 62, 652 (1990).

7. C. R. Martin, D. T. Mitchell, in Electroanalytical Chemistry, A Series of Advances, A. J. Bard, I. Rubinstein, Eds., Marcel Dekker: New York, 1999, Vol. 21, p. 1.

8. T. Thurn-Albrecht, J. Schotter, G. A. Kästle, N. Emley, T. Shibauchi, L. Krusin-Elbaum, K. Guarini, C. T. Black, M. T. Tuominen, T. P. Russel, Science 290, 2126 (2000).

9. E. Jeoung, T. H. Galow, J. Schotter, M. Bal, A. Ursache, M. T. Tuominen, C. M. Stafford, T. P. Russel, V. M. Rotello, Langmuir 17, 6396 (2001).

10. B. B. Lakshmi, C. J. Patrissi, C. R. Martin, Chem. Mater. 9, 2544 (1997).

11. C. J. Patrissi, C. R. Martin, J. Electrochem. Soc. 146, 3176 (1999).

12. N. Li, C. R. Martin, B. Scrosati, J. Power Sources 97-98, 240 (2001).

13. G. Che, K. B. Jirage, E. R. Fisher, C. R. Martin, H. Yoneyama, J. Electrochem. Soc. 144, 4296 (1997).

14. J. W. Diggle, T. C. Downie, C. W. Goulding, Chem. Rev. 69, 365 (1969).

15. A. Despic, V. P. Parkhutik, in Modern Aspects of Electrochemistry, J. O. Bockris, R. E. White, B. E. Conway, Eds., Plenum Press: New York, 1989, Vol. 20, p. 401.

16. A. T. Shawaqfeh, R. E. Baltus, J. Membr. Sci. 157, 147 (1999).

17. G. L. Hornyak, C. J. Patrissi, C. R. Martin, J. Phys. Chem. B 101, 1548 (1997).

18. P. Bocchetta, C. Sunseri, A. Bottino, G. Capannelli, G. Chiavarotti, S. Piazza, F. D. Quarto, J. Appl. Electrochem. 32, 977 (2002).

19. Y. Piao, H. Lim, J. Y. Chang, W.-Y. Lee, H. Kim, Electrochim. Acta 50, 2997 (2005).

20. M. Tian, S. Xu, J. Wang, N. Kumar, E. Wertz, Q. Li, P. M. Campbell, M. H. W. Chan, T. E. Mallouk, Nano Lett. 5, 697 (2005). 
21. G. Patermarakis, J. Electroanal. Chem. 404, 69 (1996).

22. R. C. Furneaux, W. R. Rigby, A. P. Davidsons, Porous Films and Methods Forming Them, USA, Patent number 4,687,551 (1987).

23. J. C. A. Foss, G. L. Hornyak, J. A. Stockert, C. R. Martin, J. Phys. Chem. 98, 2963 (1994).

24. Z. Zhang, D. Gekhtman, M. S. Dresselhaus, J. Y. Ying, Chem. Mater. 11, 1659 (1999).

25. C. A. Foss, Jr., in Metal Nanoparticles, Synthesis, Characterization and Applications, D. L. Feldheim, J. C. A. Foss, Eds., Marcel Dekker: New York, 2002, p. 119.

26. T. Parpaleis, J. M. Laval, M. Majda, C. Bourdillon, Anal. Chem. 64, 641 (1992).

27. A. Mozalev, S. Magaino, H. Imai, Electrochim. Acta 46, 2825 (2001).

28. C. C. Harrell, S. B. Lee, C. R. Martin, Anal. Chem. 75, 6861 (2003).

29. P. Apel, Radiat. Meas. 34, 559 (2001).

30. P. Y. Apel, Y. E. Korchev, Z. Siwy, R. Spohr, M. Yoshida, Nucl. Instrum. Methods Phys. Res. B 184, 337 (2001).

31. C. Trautman, W. Bruchle, R. Spohr, J. Vetter, N. Angert, Nucl. Instrum. Methods Phys. Res. Sect. $B$ 111, 70 (1996).

32. L. Klintberg, M. Lindberg, G. Thornell, Nucl. Instrum. Methods Phys. Res. Sect. B 184, 536 (2001).

33. R. L. Fleisher, P. B. Price, R. M. Walker, Nuclear Tracks in Solids: Principle and Applications, University of California Press: Berkley, CA, 1975.

34. Z. Siwy, P. Apel, D. Baur, D. D. Dobrev, Y. E. Korchev, R. Neumann, R. Spohr, C. Trautmann, K.-O. Voss, Surf. Sci. 532, 1061 (2003).

35. R. Spohr, Methods and Device to Generate a Predetermined Number of Ion Tracks, Germany, Patent number DE 2951376 C2 (1983).

36. E. Ferain, R. Legras, Nucl. Instrum. Methods B 174, 116-122 (2001).

37. N. Li, S. Yu, C. C. Harrell, C. R. Martin, Anal. Chem. 76, 2025 (2004).

38. C. P. Bean, W. De Sorbo, US Patent 3,770,532-19731 106 (9 February 1968).

39. Z. Siwy, D. Dobrev, R. Neumann, C. Trautmann, K. Voss, German and US patent, registration on 26.02.2002, no. 10208 023.2, Verfahren zur Herstellung von Nanostrukturen in Membranen und Asymmetrische Membran, Appl. Phys. A 76, 781 (2003).

40. P. Scopece, L. A. Baker, P. Ugo, C. R. Martin, Nanotechnology 17, 3951 (2006).

41. V. A. Oleinikof, Y. V. Tolmachyova, V. V. Berezkin, A. I. Vilensky, B. V. Mchedlishvili, Radiat. Meas. 25, 713 (1995).

42. C. R. Martin, Science 266, 1961 (1994).

43. L. D.-D. Pra, E. Ferain, R. Legras, S. Demoustier-Champagne, Nucl. Instrum. Methods Phys. Res. B 196, 81 (2002).

44. P. Ugo, L. M. Moretto, G. A. Mazzocchin, P. Guerriero, C. R. Martin, Electroanalysis 10, 1168 (1998).

45. M. Tian, J. Wang, J. Kurtz, T. E. Mallouk, M. H. W. Chan, Nano Lett. 3, 919 (2003).

46. W. Kautek, S. Reetz, S. Pentzien, Electrochim. Acta 40, 1461 (1995).

47. C. Schönenberger, B. M. I. v. d. Zande, L. G. J. Fokkink, M. Henny, C. Schmid, M. Krüger, A. Bachtold, R. Huber, H. Birk, U. Staufer, J. Phys. Chem. B 101, 5497 (1997).

48. M. L. Tian, J. Wang, J. Snyder, J. Kurtz, Y. Liu, P. Schiffer, T. E. Mallouk, M. H. W. Chan, Appl. Phys. Lett. 83, 1620 (2003).

49. J. Wang, M. Tian, T. E. Mallouk, M. H. W. Chan, J. Phys. Chem. B 108, 841 (2004).

50. J. G. Wang, M. L. Tian, T. E. Mallouk, M. H. W. Chan, Nano Lett. 4, 1313 (2004).

51. L. Wang, K. Yu-Zhang, A. Metrot, P. Bonhomme, M. Troyon, K. Ounadjela, A. Fert, Thin Solid Films 288, 86 (1996).

52. L. Piraux, J. M. George, J. F. Despres, C. Leroy, E. Ferain, R. Legras, Appl. Phys. Lett. 65, 2484 (1994). 
53. C. J. Brumlik, C. R. Martin, K. Tokuda, Anal. Chem. 64, 1201 (1992).

54. B. M. I. v. d. Zande, M. R. Böhmer, L. G. J. Fokkink, C. Schönenbergher, Langmuir 16, 451 (2000).

55. X. Y. Zhang, L. D. Zhang, Y. Lei, L. X. Zhao, Y. Q. Mao, J. Mater. Chem. 11, 1732 (2001).

56. L. Piraux, S. Dubois, S. D. Champagne, Nucl. Instrum. Methods Phys. Res. B 131, 357 (1997).

57. H. Chiriac, A. E. Moga, M. Urse, T.-A. Óvári, Sens. Actuators A 106, 348 (2003).

58. J. Verbeeck, O. I. Lebedev, G. Van Tendeloo, L. Cagnon, C. Bougerol, G. Tourillon, J. Electrochem. Soc. 150, E468 (2003).

59. G. Tourillon, L. Pontonnier, J. P. Levy, V. Langlais, Electrochem. Solid State Lett. 3, 20 (2000).

60. T. M. Whitney, J. S. Jiang, P. C. Searson, C. L. Chien, Science 261, 1316 (1993).

61. Y. Konishi, M. Motoyama, H. Matsushima, Y. Fukunata, R. Ishii, Y. Ito, J. Electroanal. Chem. 559, 149 (2003).

62. K. R. Pirota, D. Navas, M. Hernández-Vélez, K. Nielsch, M. Vásquez, J. Alloys Compd. 369, 18 (2004).

63. M. Platt, R. A. W. Dryfe, E. P. L. Roberts, Electrochim. Acta 49, 3937 (2004).

64. M. Platt, R. A. W. Dryfe, E. P. L. Roberts, Electrochim. Acta 48, 3037 (2003).

65. M. Zheng, G. Li, X. Zhang, S. Huang, Y. Lei, L. Zhang, Chem. Mater. 13, 3859 (2001).

66. S. A. Sapp, B. Lakshmi, C. R. Martin, Adv. Mater. 11, 402 (1999).

67. A. L. Prieto, M. S. Sander, M. S. M. González, R. Gronsky, T. Sands, A. M. Stacy, J. Am. Chem. Soc. 123, 7160 (2001).

68. M. Paunovic, M. Schlesinger, Fundamentals of Electrochemical Deposition, Electrochemical Society Series, Wiley-Interscience: New York, 1998.

69. B. Brunetti, P. Ugo, L. M. Moretto, C. R. Martin, J. Electroanal. Chem. 491, 166 (2000).

70. M. Wirtz, C. R. Martin, Adv. Mater. 15, 455 (2003).

71. K. B. Jirage, J. C. Hulteen, C. R. Martin, Science 278, 655 (1997).

72. J. C. Hulteen, K. B. Jirage, C. R. Martin, J. Am. Chem. Soc. 120, 6603 (1998).

73. K. B. Jirage, J. C. Hulteen, C. R. Martin, Anal. Chem. 71, 4913 (1999).

74. S. Demoustier-Champagne, M. Delvaux, Mater. Sci. Eng. C 15, 269 (2001).

75. B. Bercu, I. Enculescu, R. Spohr, Nucl. Instrum. Methods B 225, 497 (2004).

76. R. A. W. Dryfe, A. O. Simm, B. Kralj, J. Am. Chem. Soc. 125, 13014 (2003).

77. Y.-L. Tai, H. Teng, Chem. Mater. 16, 338 (2004).

78. X. Y. Yuan, G. S. Wu, T. Xie, Y. Geng, Y. Lin, G. W. Meng, L. D. Zhang, Solid State Sci. 6, 735 (2004).

79. P. Göring, E.Pippel, H. Hofmeister, R. B. Wehrspohn, M. Steinhart, U. Gösele, Nano Lett. 4, 1121 (2004).

80. M. Lahav, T. Sehayek, A. Vaskevich, I. Rubinstein, Angew. Chem. Int. Ed. 42, 5576 (2003)

81. C. A. Goss, D. H. Charych, M. Majda, Anal. Chem. 63, 85 (1991).

82. S. Yu, N. Li, J. Wharton, C. R. Martin, Nano Lett. 3, 815 (2003).

83. P. Ugo, N. Pepe, L. M. Moretto, M. Battagliarin, J. Electroanal. Chem. 560, 51 (2003).

84. M. L. Sandrock, C. D. Pibel, F. M. Geiger, C. A. Foss, Jr., J. Phys. Chem. B 103, 2668 (1999).

85. N. A. F. Al-Rawashdeh, M. L. Sandrock, C. J. Seugling, C. A. Foss, Jr., J. Phys. Chem. B 102, 361 (1998).

86. (a) P. Ugo, L. M. Moretto, F. Vezzà, Chemphyschem 3, 917 (2002). (b) P. Ugo, L. M. Moretto, F. Vezzà, in Sensors Update, H. Baltes, G. K. Fedder, J. G. Korvink, Eds., Wiley-VCH: Weinheim, 2003, Vol. 12, p. 121.

87. P. Ugo, in Encyclopedia of Sensors, C. A. Grimes, E. C. Dickey, M. V. Pishko, Eds., American Scientific Publishers: Stevenson Ranch, USA, 2006, Vol. 8, p. 67.

88. J. C. Hulteen, V. P. Menon, C. R. Martin, J. Chem. Soc. Faraday Trans. 92, 4029 (1996).

89. I. F. Cheng, L. D. Whiteley, C. R. Martin, Anal. Chem. 61, 762 (1989). 
90. C. Amatore, in Physical Electrochemistry, I. Rubinstein, Ed., Marcel Dekker: New York, 1995, p. 131.

91. L. M. Moretto, N. Pepe, P. Ugo, Talanta 62, 1055 (2004).

92. A. J. Bard, L. Faulkner, Electrochemical Methods, Wiley: New York, 2000.

93. R. Greef, R. Peat, L. M. Peter, D. Pletcher, J. Robinson, Instrumental Methods in Electrochemistry, Ellis Horwood Ltd.: Chichester, UK, 1985.

94. E. Sabatani, J. Rubinstein, J. Phys. Chem. B 91, 6663 (1987).

95. C. Amatore, J. M. Saveant, D. Tessier, J. Electroanal. Chem. 147, 39 (1983).

96. R. S. Nicholson, Anal. Chem. 37, 1351 (1965).

97. P. Ugo, L. M. Moretto, S. Bellomi, V. P. Menon, C. R. Martin, Anal. Chem. 68, 4160 (1996).

98. H. A. O. Hill, Y. Nakagawa, F. Marken, R. G. Comptom, J. Phys. Chem. 100, 17395 (1996).

99. M. J. Eddowes, H. A. O. Hill, J. Chem. Soc. Chem. Commun. (1977) 771.

100. P. M. Allen, H. A. O. Hill, N. J. Walton, J. Electroanal. Chem. 178, 69 (1984).

101. M. J. Eddowes, H. A. O. Hill, J. Am. Chem. Soc. 101, 4461 (1979).

102. T. Sagara, H. Murakami, S. Igarashi, H. Sato, K. Niki, Langmuir 7, 3190 (1991).

103. T. Sagara, K. Niwa, A. Sone, C. Innen, K. Niki, Langmuir 6, 254 (1990).

104. R. Gasparac, B. J. Taft, M. A. Lapierre-Devlin, A. D. Lazareck, J. M. Xu, S. O. Kelly, J. Am. Chem. Soc. 126, 12270 (2004).

105. K. Krishnamoorthy, C. G. Zoski, Anal. Chem. 77, 5068 (2005).

106. E. Finot, E. Bourillot, R. Meunier-Prest, Y. Lacroute, G. Legay, M. Cherkaoui-Malki, N. Latruffe, O. Siri, P. Braunstein, A. Dereux, Ultramicroscopy 97, 441 (2003).

107. J. Li, H. T. Ng, A. Cassell, W. Fan, H. Chen, Q. Ye, J. Koehne, J. Han, M. Meyyappan, Nano Lett. 3, 597 (2003).

\subsection{SINGLE PARTICLE DEPOSITION ON NANOMETER ELECTRODES}

\section{Anthony Kucernak}

Department of Chemistry, Imperial College London, London SW7 2AZ, UK

\subsubsection{Introduction}

This section describes the electrochemical deposition of single particles onto electrodes of nanometer dimensions. Methods for producing sharp tips from a range of materials have been discussed in previous sections of this work and by Melmed (1), and more recently with specific reference to electrochemical systems (2-4). Arrigan has given a review of some of the applications to which such insulated electrodes have been put (5). This section will consider both the deposition of material on nanometer-sized electrodes and the uses of such composite systems. The use of these nanoelectrodes in studying biological systems and enzymes will not be covered. There are a number of methods which in principle allow the formation of a nanoelectrode-film/particle composite (Figure 16.3.1):

(a) direct physical contact of electrode to particle;

(b) electrochemical deposition of particle or film;

(c) electrophoretic deposition of particles. 